\title{
Terceirizações na área da saúde no Brasil: reflexos no Sistema Único de Saúde - SUS, nas políticas sociais e nos trabalhadores
}

\author{
Outsourcing in healthcare in Brazil: \\ reflexes in the Sistema Único de Saúde - SUS, \\ in social policies and workers
}

Subcontratación en el área de salud en Brasil: reflexiones sobre el Sistema Único de Saúde - SUS, políticas sociales y trabajadores

Fábio CEGATTI ${ }^{(1)}$

Leonardo CARNUT ${ }^{(2)}$

Áquilas MENDES ${ }^{(1,3)}$

Recebido: 31 jul 2020

Revisado: 24 ago 2020

Aceito: 8 set 2020

Autor de correspondência:

Áquilas Mendes

aquilasmendes@gmail.com

Conflito de interesses:

Os autores declaram não haver nenhum interesse profissional ou pessoal que possa gerar conflito de interesses em relação a este manuscrito.

\footnotetext{
${ }^{(1)}$ Universidade de São Paulo - USP, Faculdade de Saúde Pública - FSP, São Paulo, SP, Brasil. (2)Universidade Federal de São Paulo - Unifesp, Centro do Desenvolvimento do Ensino Superior em Saúde, São Paulo, SP, Brasil.

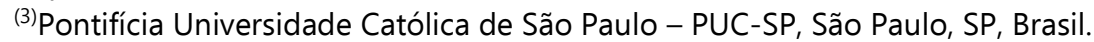

\section{Resumo}

Este estudo tem como objetivo realizar uma revisão sobre as terceirizações na área da saúde no Brasil, em termos de seus reflexos para o sistema de saúde, para as políticas sociais e para o trabalhador da saúde. Trata-se de uma revisão integrativa que a partir do objetivo identificou-se os itens-chave: "terceirizações" e "área da saúde". Do primeiro (terceirizações) derivou-se os descritores: "parcerias em saúde", "parceria públicoprivada", "serviços terceirizados", "privatização", "mercantilização" e "organização social". Do item "área da saúde" derivou-se os seguintes descritores: "sistema único de saúde", "sistema de saúde", "saúde pública" e "saúde". Foi efetuada busca sistematizada no portal regional da Biblioteca Virtual em Saúde, obtendo-se 28 estudos incluídos. Para a análise dos estudos incluídos foram organizados três temas de discussão: (a) neoliberalismo, terceirização e reflexos para o sistema de saúde brasileiro, com 22 estudos; (b) políticas sociais diante do contexto neoliberal e das terceirizações na saúde, com 9 estudos; (c) o trabalhador diante do contexto neoliberal e das terceirizações na saúde, com 7 estudos. Sobre alguns resultados, observou-se que os estudos apresentam várias desvantagens das terceirizações como: a mercantilização em função dos ideais neoliberais, a crítica sobre a agilidade e eficiência que está longe de ser alcançada, a fragmentação do sistema, problemas de regulação, falta de transparência, falhas de monitoramento, problemas no estabelecimento de metas fixas, limites à inovação e criatividade, alta rotatividade profissional e impacto sob o vínculo empregatício. Sobre as vantagens apresentadas verificou-se, que dentre as mais citadas, foram a agilidade e flexibilidade na contratação de pessoal.

Descritores: Parcerias Público-Privada; Serviços Terceirizados; Privatização; Mercantilização; Organização Social. 


\section{Abstract}

This study aims to carry out a review on outsourcing in the health area in Brazil, in terms of its reflexes for the health system, for social policies and for the health worker. It is an integrative review that, based on the objective, identified the key items: "outsourcing" and "health area". From the first (outsourcing), the descriptors were derived: "health partnerships", "public-private partnership", "outsourced services", "privatization", "mercantilization" and "social organization". From the item "health area", the following descriptors were derived: "single health system", "health system", "public health" and "health". A systematic search was carried out on the regional portal of the Virtual Health Library, obtaining 28 included studies. For the analysis of the included studies, three topics of discussion were organized: (a) neoliberalism, outsourcing and reflexes to the Brazilian health system, with 22 studies; (b) social policies in the face of the neoliberal context and outsourcing in health, with 9 studies; (c) the worker in the face of the neoliberal context and outsourcing in health, with 7 studies. Regarding some results, it was observed that the studies present several disadvantages of outsourcing, such as: the commercialization according to the neoliberal ideals, the criticism about the agility and efficiency that is far from being achieved, the fragmentation of the system, regulation problems, lack of transparency, monitoring failures, problems in establishing fixed goals, limits to innovation and creativity, high professional turnover and impact under the employment relationship. Regarding the advantages presented, it was found that, among the most cited, were agility and flexibility in hiring staff.

Keywords: Public-Private Sector Partnerships; Outsourced Services; Privatization; Commodification; Social Organization.

\section{Resumen}

Este estudio tiene como objetivo realizar una revisión de la subcontratación en el área de salud en Brasil, en términos de sus reflejos para el sistema de salud, para las políticas sociales y para el trabajador de salud. Se trata de una revisión integradora que, en función del objetivo, identificó los ítems clave: "outsourcing" y "área de salud". Del primero (subcontratación), se derivaron los descriptores: "asociaciones de salud", "asociación público-privada", "servicios subcontratados", "privatización", "mercantilización" y "organización social". Del ítem "área de salud" se derivaron los siguientes descriptores: "sistema único de salud", "sistema de salud", "salud pública" y "salud". Se realizó una búsqueda sistemática en el portal regional de la Biblioteca Virtual en Salud, obteniendo 28 estudios incluidos. Para el análisis de los estudios incluidos se organizaron tres temas de discusión: (a) neoliberalismo, tercerización y reflejos al sistema de salud brasileño, con 22 estudios; (b) políticas sociales ante el contexto neoliberal y la tercerización en salud, con 9 estudios; (c) El trabajador ante el contexto neoliberal y la subcontratación en salud, con 7 estudios. En cuanto a algunos resultados, se observó que los estudios presentan varias desventajas del outsourcing, tales como: la comercialización según los ideales neoliberales, la crítica a la agilidad y eficiencia que está lejos de lograrse, la fragmentación del sistema, problemas de regulación, falta de transparencia, fallos de seguimiento, problemas en el establecimiento de objetivos fijos, límites a la innovación y creatividad, alta rotación profesional e impacto en la relación laboral. En cuanto a las ventajas presentadas, se encontró que, entre las más citadas, se encuentran la agilidad y flexibilidad en la contratación de personal.

Palabras-claves: Asociación entre el Sector Público-Privado; Servicios Externos; Privatización; Mercantilización; Organización Social.

\section{Introdução}

Em contraposição ao pensamento biomédico em saúde, em 1948 a Organização Mundial de Saúde - OMS reconfigurou o conceito de saúde defendendo-o como o completo bem-estar físico, mental e social e não apenas a ausência doenças ou enfermidades. Desde então, sua aceitação na comunidade mundial passou a ser o debate no âmbito sanitário especialmente nas décadas de 1970-80 no auge da discussão sobre a 
ISSN 2179-6750

determinação econômica e social da saúde. Em seguida, nos países latino-americanos recém-saídos de processos políticos ditatoriais, o novo conceito de saúde foi acolhido em alguns países. No Brasil, a Constituição Federal de 1988 acolheu-o em um duplo sentido: um primeiro, coletivo, que visa à promoção da saúde em comunidade e a prevenção de doenças; e, um primeiro, segundo, em decorrência da reparação do dano quando a doença já está instalada. Assim, reconheceu-se a essência e o papel fundamental do Estado na execução de políticas públicas e desta forma garantindo o direito à saúde. ${ }^{1}$

Contudo, como fruto de um processo de luta de classes, a juspositivação da saúde enquanto um direito social foi alvo de intensas negociações em âmbito institucional, a ponto de que, em nome do asseguramento do princípio da universalidade os sanitaristas e movimentos sociais em saúde abriram mão da exclusão do setor privado no sistema. Isto se configurou legalmente no artigo 199 da Constituição (em certa medida contradizendo o artigo 196 à medida que deixa livre a participação da iniciativa privada.

Em consequência, a lei orgânica da saúde, promulgada dois anos depois (1990), reafirma a participação privada no sistema por meio do artigo 24 que descreve. ${ }^{2}$

Art. 24. Quando as suas disponibilidades forem insuficientes para garantir a cobertura assistencial à população de uma determinada área, o Sistema único de Saúde (SUS) poderá recorrer aos serviços ofertados pela iniciativa privada.

Nem essa brecha permitida pelo movimento sanitário na articulação política necessária para avançar com a construção dos SUS e nem o avanço dos planos e seguros privados paralelamente ao sistema foram suficientes para contentar a sede do mercado em explorar economicamente a saúde. Após medidas de abertura da administração pública à ordem econômica (realizada por Bresser-Pereira ${ }^{3}$ ), o processo de delegação de funções, anteriormente consideradas exclusivamente públicas (portanto estatais), aos entes privados vem passando da exceção à regra, a ponto do Ministério da Saúde no artigo 2 da portaria n. 1.034/10 regulamentar o que pode, grosso modo, ser chamado de terceirização (ou seja, a participação do setor privado na gestão do público). ${ }^{4}$

Art. $2^{\circ}$ Quando as disponibilidades forem insuficientes para garantir a cobertura assistencial à população de uma determinada área, o gestor estadual ou municipal poderá complementar a oferta com serviços privados de assistência à saúde, desde que:

I - comprovada a necessidade de complementação dos serviços públicos de saúde e,

II - haja impossibilidade de ampliação dos serviços públicos de saúde.

A terceirização advém da ideia de que é possível criar um tipo de "terceiro setor" que nem é totalmente público nem totalmente privado. $E$, também pode ser entendido 
ISSN 2179-6750

como sendo um segmento social difuso que atua entre Estado e o mercado e reúne um grande número de organizações de natureza jurídica privada, mas que, segundo a legislação não devem ter fins lucrativos. A lei n. 9.790, publicada no Diário Oficial da União de 24/03/99, que dispõe da qualificação de pessoas jurídicas, sem fins lucrativos, como Organizações da Sociedade Civil de Interesse Público - OSCIP, institui e disciplina o termo de parceria, dentre outras providências. ${ }^{5}$

Segundo Santos, ${ }^{6}$ as parcerias público-privadas fazem referência a algum tipo de relação entre iguais, pautada em contratos de gestão com prazos e responsabilidades mútuas, devendo ser respeitados por ambos. Importante ressaltar que não se trata de uma relação de contratação meramente comercial, como a terceirização, nem de transferência completa de patrimônios e responsabilidades, como na privatização, não sendo criada nenhuma relação de lucratividade nas partes envolvidas, sendo mais comum trocas de experiência ou de execução de atividades com base em metas e resultados.

Contudo, o que se observa empiricamente é que, as relações existentes nesta mescla entre o público e o privado não tem sido delineada de acordo com esta classificação. Em que pese que sejam consideradas figuras jurídicas, a parceria públicoprivada (PPP), as terceirizações e a privatizações tem sido, na prática, se transformado em modelos privatizantes de gestão do SUS $^{7}$ haja vista que, em uma sociedade capitalista a ordem econômica tem prevalência sobre a organização da vida em sociedade em detrimento da planificação estatizada.

Além disso, o Estado é capitalista no que diz respeito a sua forma jurídicopolítica. Isto quer dizer que, mesmo sendo necessária a defesa da gestão pública estatizada para os serviços que operam direitos sociais (como no caso da saúde) é essencial a vigilância dos atores sociais que defendem estes direitos sobre a capacidade do Estado em drenar recursos para a sustentabilidade da lógica de mercado. ${ }^{8}$

É importante frisar que, a rigor, a relação público-privada no sistema de saúde no Brasil já existe desde os primórdios da assistência médica previdenciária - Instituto Nacional de Previdência Social - INPS, 1967 e reforçada com a criação do Instituto Nacional de Assistência Médica e Previdência Social - INAMPS, 1974. Desde então essa parceria foi aprofundada porque necessitava do setor privado para atender as demandas decorrentes da incorporação de trabalhadores formais e autônomos que contribuíssem para o INPS. ${ }^{9}$

A partir dos anos 1990 com o fortalecimento do pensamento neoliberal, levantouse a questão de não garantir a oferta de saúde baseada em equipamentos próprios e a opção em ampliar preferencialmente os equipamentos de saúde do setor privado e a desconstrução da ideia de que o bem público deveria ser produto de ação direta do 
ISSN 2179-6750

Estado. ${ }^{10}$ Isto pode ser explicado, em parte, pelo fato de que as conquistas sociais dos brasileiros como no caso do SUS, que expressa a política universal da saúde, ocorreram tardiamente já dentro de um contexto histórico de demolição considerando a direção do Estado já para o Estado neoliberal em curso. ${ }^{11}$

Portanto, nesta conjuntura dois projetos para o sistema de saúde estão postos. Esses dois projetos são antagônicos e têm grandes repercussões no que diz respeito a políticas sociais, sendo que o projeto da reforma sanitária tem como uma de suas estratégias o SUS e como diretriz a democratização do acesso, a universalidade das ações, descentralização, a melhoria dos serviços assegurando a saúde como direito de todos e dever do Estado. Em relação ao projeto privatista pautado na redução da participação do Estado, tem como estratégia as parcerias com a sociedade, responsabilizando-a a assumir os custos da crise, com concepções individualistas e fragmentadas. ${ }^{9}$

No final da década de 1990, o Relatório do Banco Mundial defendia que, com a globalização econômica, o Estado necessitava ser diferente e difundia a ideia de uma baixa efetividade na promoção do desenvolvimento, ou seja, o papel central do Estado não seria de alavancar o desenvolvimento social e econômico, mas sim de catalisador e facilitador desse desenvolvimento. ${ }^{12}$ Ainda de acordo com o Banco Mundial, as parcerias em saúde tornam-se um mecanismo chave para implantação das políticas de saúde diante da ordem econômica global e neoliberal. O documento cita que o termo "PPP" (parceria públicoprivada) é usado de maneira ampla como um guarda-chuva envolvendo diferentes relações entre o público e o privado.

Muitos autores não fazem distinção entre o termo e outros restringem a parceiros privados-lucrativos como critério diferenciador das PPPs. ${ }^{12}$ Contudo, na mesma linha de pensamento, Franco ${ }^{13}$ mostra que o Estado já não é mais suficiente para enfrentar as situações complexas e ou caóticas, tornando-se necessário um novo paradigma, para ele, o surgimento do terceiro setor. Isso significa que a própria sociedade, através de seus governantes, está descobrindo limites e com isso busca a superação dos desafios impostos através de novas explicações/concepções.

Segundo Barbosa e Malik, ${ }^{14}$ o desenvolvimento da parceria público-privada representa uma oportunidade especial de melhoria da assistência à saúde com investimentos em novas estruturas que venham suprir as deficiências crônicas do setor, mas esclarece que, para resolver os entraves destes projetos, é necessário conhecimento sobre as necessidades do sistema de saúde, objetivos e interesses do setor privado, interação com agentes públicos e de controle social e capacidade de comunicação e diálogo. 
O Sistema Único de Saúde - SUS sofre um processo de desmonte e sucateamento diante do projeto neoliberal com um intenso processo de privatização e dos processos de precarização do trabalho. ${ }^{15}$ A própria ideia de parceria público-privada cria facilidades para entrada do capital privado, compromete a própria essência do serviço público, favorece um tipo de política pública que não será mais universal e sim focal e finalmente representa a mercantilização dos serviços públicos viabilizando os interesses do capital, especialmente o financeiro. ${ }^{16}$

Além disso, verifica-se a permissão do Estado à apropriação do fundo público pelo capital, e dentro do contexto contemporâneo, sob o domínio do capital financeiro. Assiste-se a concessão de incentivos à iniciativa privada, como o aumento das renúncias fiscais, decorrentes da dedução dos gastos com planos de saúde no imposto de renda e das concessões fiscais às entidades privadas sem fins lucrativos, enfraquecendo a capacidade de arrecadação do Estado e prejudicando o financiamento do SUS. ${ }^{17}$

Percebe-se que a relação entre o público e o privado está cada vez mais entrelaçada, levando a um gradiente de estratificação na oferta e utilização dos serviços de saúde que se apresenta hoje como um grande limite na reconstrução de uma forma essencialmente pública e estatal de prestação dos serviços. ${ }^{18}$ Mesmo que a terceirização dos serviços de saúde desenvolvida pelo setor privado somente possa ocorrer em atividades complementares, como decidiu o Supremo Tribunal Federal; o ponto de criticidade deste quadro administrativo surge do diagnóstico (pouco preciso) das "falhas de governança" em traçar metas (eficiência) e resultados (efetividade). ${ }^{19,20}$

Diante desse cenário, este estudo tem como objetivo realizar uma revisão sobre as terceirizações na área da saúde no Brasil, em termos de seus reflexos para o sistema de saúde, para as políticas sociais e para o trabalhador da saúde.

\section{Metodologia}

O presente estudo trata-se de uma revisão integrativa, ${ }^{21}$ com foco nas terceirizações em saúde. Buscou-se de forma sistematizada no portal Biblioteca Virtual em Saúde - BVS todas as publicações indexadas relativas aos objetivos desta pesquisa.

Foi elaborada a seguinte pergunta de pesquisa: O que existe na literatura sobre as reflexões referentes às terceirizações na área da saúde no Brasil? A partir desta pergunta, foram identificados os itens-chave: "terceirizações" e "área da saúde". Do primeiro item-chave (terceirizações) derivou-se os seguintes descritores: "parcerias em saúde", "parceria público-privada", "serviços terceirizados", "privatização", "mercantilização" e "organização social". Ainda, item "área da saúde" 
derivou-se os seguintes descritores: "sistema único de saúde", "sistema de saúde", "saúde pública" e "saúde".

Foram utilizados os operadores Booleanos "and" e ("or" e "and") para estabelecermos o funil e filtrarmos os artigos de interesse. Inicialmente, foram digitados individualmente na busca avançada do banco de dados da BVS e indexados, com pesquisa realizada no período de 01 a 31 de outubro de 2018.

Após essa etapa, foram avaliados os títulos de acordo com os propósitos desta pesquisa, ou seja, foram selecionados aqueles que retrataram claramente as parcerias público-privadas ou terceirizações ou privatizações ou organizações sociais, obtendo um total de 100 publicações na sintaxe final, sendo posteriormente excluídas 47 publicações repetidas, obtendo um total de 53 publicações. Dessas, foi efetuada a leitura dos títulos e, em seguida a leitura dos resumos. Nessa primeira leitura dos títulos foram excluídos 19 artigos e na leitura dos resumos foram excluídos 4 artigos, restando 30 artigos. Os critérios de exclusão referiram-se às publicações com foco na saúde suplementar; publicações em língua estrangeira; não especificidade com a área da saúde; e os artigos que não dispunham de resumos. Também foram excluídas as publicações cujo assunto foi a "privatização da saúde" não focada nas parcerias público-privadas ou nas terceirizações, por entendermos que são conceitos diferentes, ou seja, juridicamente falando as privatizações "senso estrito" envolvem alienação de ativos e bens públicos e as parcerias devem ser entendidas como uma espécie de concessão. Por fim, foram excluídas 2 publicações indisponíveis para leitura na integra. Assim, restaram 28 publicações incluídas.

Devido a característica do assunto da revisão em tela, optou-se por incluir diferentes modalidades textuais no conjunto das publicações incluídas, a fim de assegurar um número considerável de estudos. Dentre as várias modalidades, destacam-se: artigos, teses, editoriais, reportagem, dissertação e livro.

A seguir, apresenta-se o Fluxograma 1 referente ao processo de seleção dos artigos incluídos nesta revisão integrativa, conforme mencionado anteriormente.

Para a análise das publicações incluídas foram organizados três temas de discussão: (a) neoliberalismo, terceirização e reflexos para o sistema de saúde brasileiro, com 22 estudos; (b) políticas sociais diante do contexto neoliberal e das terceirizações na saúde, com 9 estudos; (c) o trabalhador diante do contexto neoliberal e das terceirizações na saúde, com 7 estudos. 

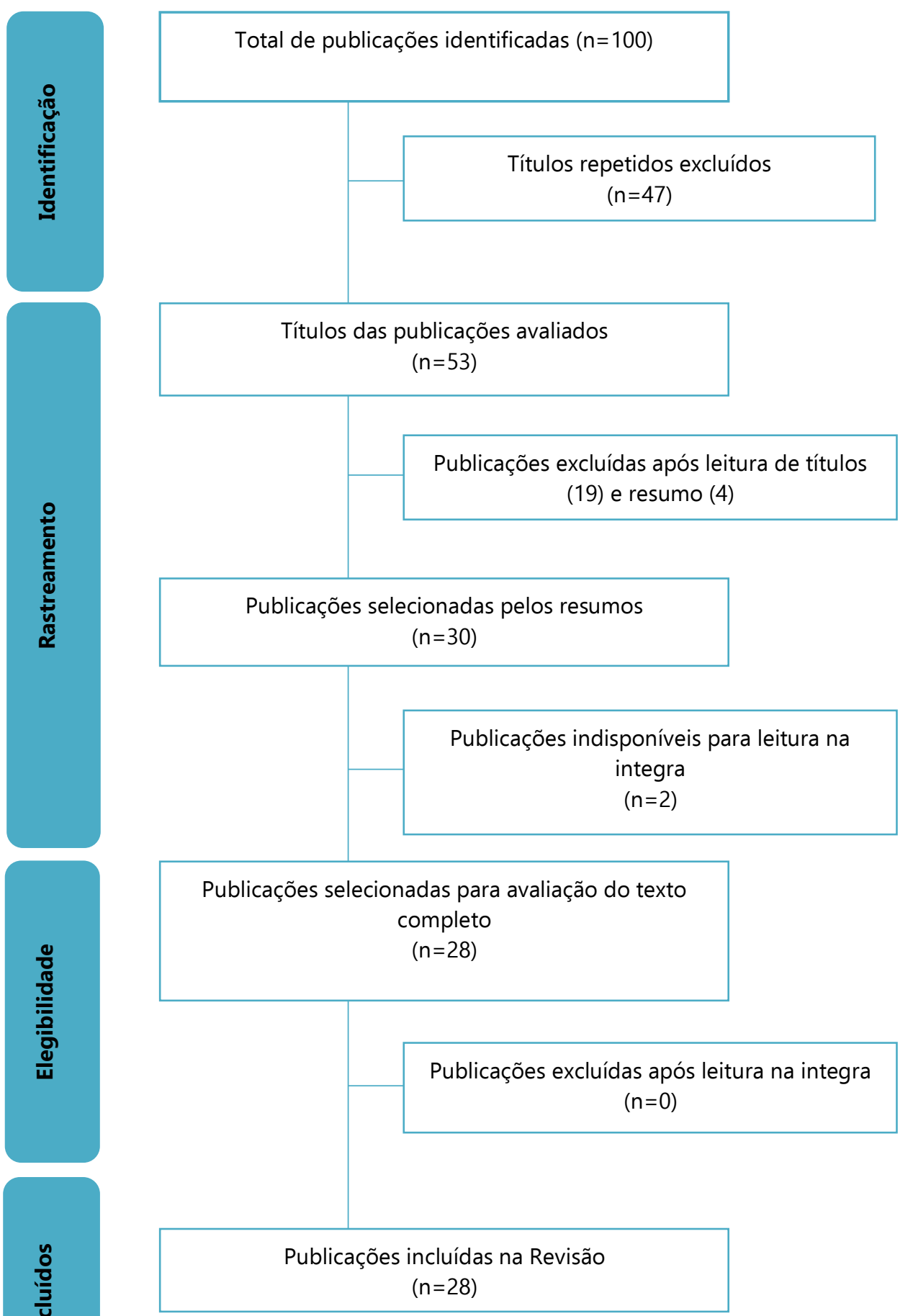

Figura 1. Fluxograma do processo de seleção das publicações incluídas na revisão integrativa Fonte: Elaborado pelos autores (2020). 


\section{Resultados e discussão}

Dentre os estudos incluídos a maior parte deles refere-se à artigos científicos (17), sendo os demais, respectivamente, teses (5), editoriais (3), dissertações (1), livro (1) e reportagem (1). Quanto às metodologias de investigação utilizadas nos estudos, a maior parte delas diz respeito à estudos de caso (7) e ensaios (7), seguidas dos estudos descritivos (3), narrativos (3), multimétodos (2), reflexões quantiqualitativas ou puramente qualitativos (2), revisões de literatura (2), historiografia (1) e resenha de livro (1).

Quando à identificação dos temas relativos à relação terceirização e o SUS, 22 estudos trouxerem elementos sobre os reflexos diretos da terceirização no SUS, 9 estudos apresentaram reflexos da terceirização nas políticas sociais como um todo, e apenas 7 trouxeram elementos sobre a relação da terceirização sobre os trabalhadores do sistema.

Assim, em seguida foram analisados os temas segundo o que os estudos apresentaram acerca da relação terceirizações e o SUS: (a) neoliberalismo, terceirização e reflexos para o sistema de saúde brasileiro; (b) políticas sociais diante do contexto neoliberal e das terceirizações na saúde; (c) o trabalhador diante do contexto neoliberal e das terceirizações na saúde.

O Quadro 1 apresenta uma síntese dos principais elementos identificados nos artigos incluídos ${ }^{22-49}$ que relacionam as terceirizações em saúde com os reflexos no SUS, nas políticas sociais e nos trabalhadores da saúde.

\begin{tabular}{|l|c|c|c|c|c|}
\hline \multicolumn{1}{|c|}{ Autor(es) } & Tipo & Método & Reflexos no SUS & $\begin{array}{c}\text { Reflexo nas } \\
\text { políticas sociais }\end{array}$ & $\begin{array}{c}\text { Reflexos no } \\
\text { trabalhador }\end{array}$ \\
\hline $\begin{array}{l}\text { Ribeiro } \\
\text { GMA, } \\
2018^{22}\end{array}$ & Tese & Historiográfico & $\begin{array}{c}\text { Governos militares } \\
\text { incentivam o setor } \\
\text { privado; } \\
\text { Com a terceirização se } \\
\text { justifica a regulação } \\
\text { pelo Estado; } \\
\text { Crise do Estado de } \\
\text { Bem Estar Social em } \\
\text { seu nascimento; } \\
\text { Crise econômica } \\
\text { provocada pela crise } \\
\text { do petróleo em 1973; } \\
\text { Inconformismo dos } \\
\text { contribuintes. }\end{array}$ & - & $\begin{array}{c}\text { Causa impacto no } \\
\text { tempo de vínculo } \\
\text { empregatício } \\
\text { (maior } \\
\text { rotatividade). }\end{array}$ \\
& & & \\
& & & \\
\hline
\end{tabular}


ISSN 2179-6750

\begin{tabular}{|c|c|c|c|c|c|}
\hline Autor(es) & Tipo & Método & Reflexos no SUS & $\begin{array}{l}\text { Reflexo nas } \\
\text { políticas sociais }\end{array}$ & $\begin{array}{l}\text { Reflexos no } \\
\text { trabalhador }\end{array}$ \\
\hline $\begin{array}{l}\text { Machado } \\
C V, 2018^{23}\end{array}$ & Editorial & Narrativo & $\begin{array}{l}\text { Entrelaçamento } \\
\text { público-privado } \\
\text { complexifica a oferta. }\end{array}$ & $\begin{array}{c}\text { Esta mescla trava } \\
\text { a plena } \\
\text { implementação de } \\
\text { políticas } \\
\text { universais na } \\
\text { saúde. }\end{array}$ & - \\
\hline $\begin{array}{l}\text { Melo MP, } \\
\text { Lessa SEC, } \\
2017^{24}\end{array}$ & Artigo & $\begin{array}{c}\text { Reflexão Quali- } \\
\text { quantitativa }\end{array}$ & $\begin{array}{c}\text { Fundo público como } \\
\text { garantidor a priori do } \\
\text { lucro burguês; } \\
\text { Os contratos que } \\
\text { favorecem as } \\
\text { Parcerias Público- } \\
\text { Privada. }\end{array}$ & $\begin{array}{l}\text { Terceirização está } \\
\text { em sintonia com } \\
\text { os projetos do } \\
\text { Banco Mundial; } \\
80 \% \text { OSs das } \\
\text { Fundações e } \\
\text { Associações; } \\
\text { Sem Fins Lucros } \\
\text { (FASFIL) estão sob } \\
\text { investigação do } \\
\text { Ministério Público; } \\
\text { Falta de } \\
\text { transparência na } \\
\text { execução e } \\
\text { superfaturamento. }\end{array}$ & - \\
\hline $\begin{array}{l}\text { Barreto FL, } \\
\text { Souza CC, } \\
\text { Luedy A, } \\
\text { Mendes } \\
\text { VLPS, } \\
\text { Tahara ÂTS, } \\
2017^{25}\end{array}$ & Artigo & $\begin{array}{l}\text { Estudo descritivo, } \\
\text { abordagem } \\
\text { quantitativa e } \\
\text { qualitativa }\end{array}$ & $\begin{array}{c}\text { Parcerias Público- } \\
\text { Privada como uma } \\
\text { espécie de concessão } \\
\text { do público para o } \\
\text { privado; } \\
\text { Experiência bem } \\
\text { sucedida de PPP } \\
\text { (Hospital de Subúrbio } \\
\text { na Bahia, acreditado } \\
\text { pleno pela ONU); } \\
\text { Escolha do parceiro } \\
\text { privado deve levar em } \\
\text { consideração a } \\
\text { experiência em gestão } \\
\text { de unidades } \\
\text { credenciadas. }\end{array}$ & - & - \\
\hline $\begin{array}{l}\text { Lara L, } \\
\text { Bernardes } \\
\text { AG, } \\
\text { Guareschi } \\
\text { NMF, } \\
2016^{26}\end{array}$ & Artigo & Ensaio & $\begin{array}{c}\text { Separar o público do } \\
\text { privado, defendendo } \\
\text { que o público; } \\
\text { Definir os papéis entre } \\
\text { o público e o privado; } \\
\text { Problema em } \\
\text { normalizar a vida por } \\
\text { meio dos interesses } \\
\text { mercantis; } \\
\text { Pensamento }\end{array}$ & - & $\begin{array}{l}\text { Segmentação dos } \\
\text { trabalhadores e } \\
\text { sua perda da força } \\
\text { social (fragilização } \\
\text { das lutas } \\
\text { coletivas); } \\
\text { As questões } \\
\text { trabalhistas } \\
\text { passam a ser } \\
\text { tratadas entre } \\
\text { duas empresas (a } \\
\text { contratante e a }\end{array}$ \\
\hline
\end{tabular}


ISSN 2179-6750

\begin{tabular}{|c|c|c|c|c|c|}
\hline Autor(es) & Tipo & Método & Reflexos no SUS & $\begin{array}{c}\text { Reflexo nas } \\
\text { políticas sociais }\end{array}$ & $\begin{array}{l}\text { Reflexos no } \\
\text { trabalhador }\end{array}$ \\
\hline & & & $\begin{array}{l}\text { neoliberal não tem } \\
\text { como objeto o } \\
\text { fortalecimento de um } \\
\text { Estado que se } \\
\text { efetivem os direitos } \\
\text { sociais. }\end{array}$ & & $\begin{array}{l}\text { contratada) e não } \\
\text { mais entre a } \\
\text { organização e o } \\
\text { trabalhador. }\end{array}$ \\
\hline $\begin{array}{l}\text { Feitosa RL, } \\
\text { Montenegr } \\
\text { o AV, } \\
2015^{27}\end{array}$ & Artigo & $\begin{array}{l}\text { Revisão de } \\
\text { literatura }\end{array}$ & $\begin{array}{c}\text { Problema na } \\
\text { monitorização dos } \\
\text { custos cuja } \\
\text { expectativa está na } \\
\text { sua redução; } \\
\text { Considerar as fraudes, } \\
\text { pela má avaliação dos } \\
\text { chamados "custos } \\
\text { escondidos", "custos } \\
\text { indiretos" e "custos } \\
\text { sociais". }\end{array}$ & - & - \\
\hline $\begin{array}{l}\text { Albuquerqu } \\
\text { e MSV, } \\
\text { Morais } \\
\text { HMM, Lima } \\
\text { LP, } 2015^{28}\end{array}$ & Artigo & $\begin{array}{l}\text { Estudo de caso } \\
\text { com pesquisa } \\
\text { documental e } \\
\text { entrevistas }\end{array}$ & $\begin{array}{l}\text { Fernando Henrique } \\
\text { Cardoso incentivou a } \\
\text { tendência de } \\
\text { privatização do SUS } \\
\text { por meio das } \\
\text { contratualizações; } \\
\text { As contratualizações } \\
\text { tendem a ocorrer por } \\
\text { caminhos tortuosos, } \\
\text { obscuros e } \\
\text { burocráticos dentro } \\
\text { de um estado } \\
\text { hegemonizado por } \\
\text { forças sociais de } \\
\text { interesses privados; } \\
\text { Relações entre o } \\
\text { Estado e parceiros } \\
\text { privados defendem a } \\
\text { mercantilização da } \\
\text { saúde; } \\
\text { Com a terceirização } \\
\text { corre-se o risco de } \\
\text { deterioração da } \\
\text { qualidade dos serviços } \\
\text { prestados; } \\
\text { isoladas e dificulta o } \\
\text { mecanismo de }\end{array}$ & - & - \\
\hline
\end{tabular}


ISSN 2179-6750

\begin{tabular}{|c|c|c|c|c|c|}
\hline Autor(es) & Tipo & Método & Reflexos no SUS & $\begin{array}{c}\text { Reflexo nas } \\
\text { políticas sociais }\end{array}$ & $\begin{array}{l}\text { Reflexos no } \\
\text { trabalhador }\end{array}$ \\
\hline & & & $\begin{array}{c}\text { implantação de } \\
\text { estruturação das } \\
\text { redes; } \\
\text { Os secretários } \\
\text { defendem o processo } \\
\text { de contratualização. }\end{array}$ & & \\
\hline $\begin{array}{l}\text { Campos } \\
\text { CMS, Viana } \\
\text { N, Soares } \\
\text { CB, } 2015^{29}\end{array}$ & Artigo & Ensaio & - & $\begin{array}{l}\text { Modelo neoliberal } \\
\text { e privatista gera } \\
\text { políticas sociais } \\
\text { paliativas em } \\
\text { substituição às } \\
\text { políticas } \\
\text { estruturais. }\end{array}$ & $\begin{array}{c}\text { Aumento na busca } \\
\text { pela } \\
\text { produtividade; } \\
\text { Corrosão dos } \\
\text { direitos } \\
\text { trabalhistas; } \\
\\
\text { Contratos } \\
\text { temporários, } \\
\text { aumento do } \\
\text { tempo para } \\
\text { aposentadoria. }\end{array}$ \\
\hline $\begin{array}{l}\text { Scheffer M, } \\
2015^{30}\end{array}$ & Editorial & Narrativo & - & $\begin{array}{c}\text { Participação do } \\
\text { capital estrangeiro } \\
\text { na saúde foi fruto } \\
\text { da vitória } \\
\text { envolvendo os } \\
\text { interesses de } \\
\text { hospitais privados } \\
\text { (alguns Parcerias } \\
\text { Público-Privada), } \\
\text { indústria } \\
\text { farmacêutica e } \\
\text { planos de saúde. }\end{array}$ & - \\
\hline
\end{tabular}


ISSN 2179-6750

\begin{tabular}{|c|c|c|c|c|c|}
\hline Autor(es) & Tipo & Método & Reflexos no SUS & $\begin{array}{c}\text { Reflexo nas } \\
\text { políticas sociais }\end{array}$ & $\begin{array}{l}\text { Reflexos no } \\
\text { trabalhador }\end{array}$ \\
\hline $\begin{array}{l}\text { Contreiras } \\
\text { H, Matta } \\
\text { GC, } 2015^{31}\end{array}$ & Artigo & $\begin{array}{l}\text { Levantamento } \\
\text { bibliográfico e } \\
\text { análise } \\
\text { documental }\end{array}$ & $\begin{array}{l}\text { Administração } \\
\text { gerencial não cumpre } \\
\text { a eficiência que por } \\
\text { sua definição exige } \\
\text { um controle financeiro } \\
\text { estrito; } \\
\text { 96\% dos } \\
\text { estabelecimentos de } \\
\text { saúde em SP estavam } \\
\text { sob gestão privada; } \\
\text { Terceiro setor é um } \\
\text { campo de intensa } \\
\text { atividade econômica } \\
\text { indo além do campo } \\
\text { da desinteressada } \\
\text { filantropia; } \\
\text { Embora sejam } \\
\text { entidades 'sem fins } \\
\text { lucrativos' estas } \\
\text { parceiras não } \\
\text { escondem seus } \\
\text { interesses lucrativos. }\end{array}$ & - & - \\
\hline $\begin{array}{l}\text { Araújo IMM, } \\
2015^{32}\end{array}$ & Artigo & $\begin{array}{c}\text { Revisão crítica da } \\
\text { literatura }\end{array}$ & $\begin{array}{l}\text { A apropriação privada } \\
\text { da saúde é dada pelas } \\
\text { organizações sociais; } \\
\text { A terceirização e a } \\
\text { privatização da saúde } \\
\text { se transformam em } \\
\text { problemas previsíveis; } \\
\text { Fazem a transferência } \\
\text { da 'poupança pública' } \\
\text { para o setor privado e } \\
\text { lucrativo. }\end{array}$ & - & $\begin{array}{l}\text { Terceirização dos } \\
\text { recursos humanos } \\
\text { desorganiza o } \\
\text { trabalho em } \\
\text { saúde; } \\
\text { Flexibilização } \\
\text { contratos, } \\
\text { precariza o } \\
\text { trabalho e o } \\
\text { comprometimento } \\
\text { com a } \\
\text { hierarquização na } \\
\text { saúde. }\end{array}$ \\
\hline $\begin{array}{l}\text { Castro ALB, } \\
2015^{33}\end{array}$ & Tese & $\begin{array}{c}\text { Revisão } \\
\text { bibliográfica; } \\
\text { análise } \\
\text { documental; } \\
\text { análise de dados } \\
\text { secundários e } \\
\text { entrevista } \\
\text { semiestruturada }\end{array}$ & $\begin{array}{l}\text { Usa como argumento } \\
\text { que reforma nos } \\
\text { sistemas de saúde } \\
\text { ocorre pelos altos } \\
\text { custos da assistência } \\
\text { médica; } \\
\text { Justificam as parceiras } \\
\text { pela necessidade de: } \\
\text { - maior eficiência na } \\
\text { prestação de serviços } \\
\text { de saúde; }\end{array}$ & - & - \\
\hline
\end{tabular}


ISSN 2179-6750

\begin{tabular}{|c|c|c|c|c|c|}
\hline Autor(es) & Tipo & Método & Reflexos no SUS & $\begin{array}{c}\text { Reflexo nas } \\
\text { políticas sociais }\end{array}$ & $\begin{array}{l}\text { Reflexos no } \\
\text { trabalhador }\end{array}$ \\
\hline & & & $\begin{array}{l}\text { - utilizar avaliações no } \\
\text { processo de } \\
\text { incorporação } \\
\text { tecnológica e de } \\
\text { produtos em saúde; } \\
\text { - normatizar condutas; } \\
\text { - rever formas de } \\
\text { remuneração e } \\
\text { contratação de } \\
\text { prestadores em } \\
\text { função da ineficiência } \\
\text { do Estado; } \\
\text { Enfatiza a regulação } \\
\text { pública sobre os } \\
\text { diferentes arranjos } \\
\text { público-privados de } \\
\text { forma a fortalecer os } \\
\text { princípios e diretrizes } \\
\text { do SUS; } \\
\text { Prestadores privados } \\
\text { para preencherem as } \\
\text { lacunas assistenciais } \\
\text { do SUS; } \\
\text { Lógica dos interesses } \\
\text { privados e molda as } \\
\text { decisões no âmbito da } \\
\text { gestão pública. }\end{array}$ & & \\
\hline $\begin{array}{l}\text { Mendes Á, } \\
2015^{34}\end{array}$ & Artigo & Ensaio & - & $\begin{array}{c}\text { Promovem a } \\
\text { desuniversalização } \\
\text { e diminuição } \\
\text { assistencial das } \\
\text { políticas sociais }\end{array}$ & \\
\hline $\begin{array}{l}\text { Rodrigues } \\
\mathrm{CT} \text {, } \\
\text { Spagnuolo } \\
\mathrm{RS}, 2014^{35}\end{array}$ & Artigo & $\begin{array}{c}\text { Estudo de caso } \\
\text { único }\end{array}$ & $\begin{array}{l}\text { Vantagens das } \\
\text { parcerias na aquisição } \\
\text { mais rápida de } \\
\text { materiais e } \\
\text { equipamentos; } \\
\text { Defende a } \\
\text { necessidade de } \\
\text { aprimorar os } \\
\text { mecanismos de } \\
\text { controle } \\
\text { (transparência); } \\
\text { A participação social }\end{array}$ & - & $\begin{array}{l}\text { Pela limitação da } \\
\text { LRF, foi instituído } \\
\text { convênio com } \\
\text { entidade } \\
\text { filantrópica para } \\
\text { gestão em saúde } \\
\text { destacando maior } \\
\text { agilidade. }\end{array}$ \\
\hline
\end{tabular}


ISSN 2179-6750

\begin{tabular}{|c|c|c|c|c|c|}
\hline Autor(es) & Tipo & Método & Reflexos no SUS & $\begin{array}{l}\text { Reflexo nas } \\
\text { políticas sociais }\end{array}$ & $\begin{array}{l}\text { Reflexos no } \\
\text { trabalhador }\end{array}$ \\
\hline & & & $\begin{array}{l}\text { (nos conselhos } \\
\text { curadores das } \\
\text { parceiras) é bem } \\
\text { restrita e pouco } \\
\text { efetiva. }\end{array}$ & & \\
\hline $\begin{array}{l}\text { Silva VC, } \\
2014^{36}\end{array}$ & Tese & Estudo de caso & $\begin{array}{c}\text { Problemas de } \\
\text { transparência social; } \\
\text { Dificuldades de } \\
\text { monitoramento; } \\
\text { Estado não apresenta } \\
\text { ferramentas } \\
\text { regulatórias } \\
\text { (dificultando avaliação } \\
\text { dos serviços } \\
\text { prestados); } \\
\text { Relação de } \\
\text { subordinação com } \\
\text { limitação de } \\
\text { inovações gerenciais. }\end{array}$ & - & - \\
\hline $\begin{array}{l}\text { Tavares V, } \\
2014^{37}\end{array}$ & Reportagem & Ensaio & $\begin{array}{l}\text { Regime militar é } \\
\text { precursor da } \\
\text { privatização. }\end{array}$ & $\begin{array}{l}\text { Criação do Fundo } \\
\text { de Apoio ao } \\
\text { Desenvolvimento } \\
\text { Social (FAS), as } \\
\text { empresas de } \\
\text { medicina } \\
\text { passaram a contar } \\
\text { com essa fonte de } \\
\text { financiamento } \\
\text { para construção, } \\
\text { ampliação e } \\
\text { aquisição de } \\
\text { equipamentos. }\end{array}$ & - \\
\hline
\end{tabular}


ISSN 2179-6750

\begin{tabular}{|c|c|c|c|c|c|}
\hline Autor(es) & Tipo & Método & Reflexos no SUS & $\begin{array}{c}\text { Reflexo nas } \\
\text { políticas sociais }\end{array}$ & $\begin{array}{l}\text { Reflexos no } \\
\text { trabalhador }\end{array}$ \\
\hline $\begin{array}{l}\text { Leite } \\
\text { AMGN, } \\
2014^{38}\end{array}$ & Dissertação & Estudo de caso & $\begin{array}{l}\text { Instrumentos de } \\
\text { gestão flexíveis não } \\
\text { garantem a } \\
\text { transparência e } \\
\text { eficiência do serviço; } \\
\text { Necessidade de } \\
\text { aperfeiçoamento dos } \\
\text { mecanismos de } \\
\text { fiscalização do } \\
\text { terceiro setor; } \\
\text { Desburocratização } \\
\text { dos meios de } \\
\text { investigação; } \\
\text { Estabelecer novos } \\
\text { fluxos de informação } \\
\text { através de sistemas } \\
\text { informatizados. }\end{array}$ & - & - \\
\hline $\begin{array}{l}\text { Romano } \\
\text { CMC, } \\
\text { Scatena } \\
\text { JHG, } 2014^{39}\end{array}$ & Artigo & $\begin{array}{c}\text { Estudo } \\
\text { quantitativo e } \\
\text { descritivo }\end{array}$ & $\begin{array}{l}\text { Concorda com a } \\
\text { complementação do } \\
\text { setor público pelo } \\
\text { privado na saúde; } \\
\text { Entende que as falhas } \\
\text { no processo de } \\
\text { regulação do setor } \\
\text { privado; } \\
\text { Reitera que a saúde } \\
\text { privada tem que } \\
\text { conviver com a } \\
\text { pública; } \\
\text { Esclarece que a } \\
\text { eficiência e o bom } \\
\text { desempenham não } \\
\text { são particularidades } \\
\text { exclusivas dos setores } \\
\text { privados ou público. }\end{array}$ & - & - \\
\hline
\end{tabular}


ISSN 2179-6750

\begin{tabular}{|c|c|c|c|c|c|}
\hline Autor(es) & Tipo & Método & Reflexos no SUS & $\begin{array}{c}\text { Reflexo nas } \\
\text { políticas sociais }\end{array}$ & $\begin{array}{l}\text { Reflexos no } \\
\text { trabalhador }\end{array}$ \\
\hline $\begin{array}{l}\text { Paulus } \\
\text { Júnior A, } \\
2013^{40}\end{array}$ & Tese & $\begin{array}{c}\text { Estudo de caso } \\
\text { múltiplo }\end{array}$ & $\begin{array}{l}\text { A contratualização } \\
\text { deve ir além do } \\
\text { estabelecimento de } \\
\text { metas (considerar } \\
\text { dados históricos e } \\
\text { epidemiológicos); } \\
\text { Grande risco de } \\
\text { direcionar uma } \\
\text { assistência } \\
\text { fragmentada na } \\
\text { elaboração das metas } \\
\text { contratuais nos } \\
\text { serviços terceirizados; } \\
\text { O contrato de gestão } \\
\text { deve ser negociado, } \\
\text { com a participação } \\
\text { dos trabalhadores; } \\
\text { Falhas no processo de } \\
\text { monitorização destes } \\
\text { contratos alegando } \\
\text { existir dificuldades em } \\
\text { efetuar um } \\
\text { monitoramento; } \\
\text { Falta de prioridade na } \\
\text { operacionalização das } \\
\text { comissões de } \\
\text { avaliação (secretarias } \\
\text { com pouca estrutura } \\
\text { para isto). }\end{array}$ & - & - \\
\hline $\begin{array}{l}\text { Travassos C, } \\
2013^{41}\end{array}$ & Editorial & Narrativo & $\begin{array}{l}\text { Privatização do } \\
\text { cuidado da saúde } \\
\text { representa uma } \\
\text { ameaça dos direitos; } \\
\text { Falta de regulação } \\
\text { caminha com a } \\
\text { crescente } \\
\text { comercialização e de } \\
\text { modo dissimulado. }\end{array}$ & - & - \\
\hline
\end{tabular}


ISSN 2179-6750

\begin{tabular}{|c|c|c|c|c|c|}
\hline Autor(es) & Tipo & Método & Reflexos no SUS & $\begin{array}{c}\text { Reflexo nas } \\
\text { políticas sociais }\end{array}$ & $\begin{array}{l}\text { Reflexos no } \\
\text { trabalhador }\end{array}$ \\
\hline $\begin{array}{l}\text { Borges FT, } \\
2012^{42}\end{array}$ & Tese & Estudo de caso & 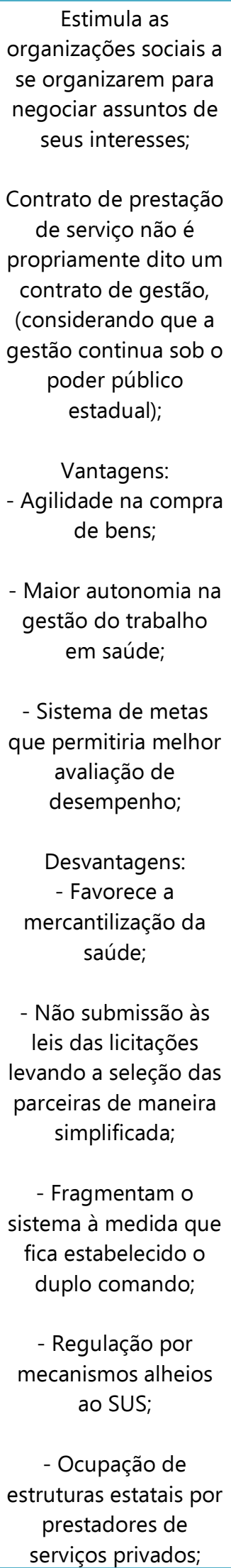 & $\begin{array}{c}\text { A política de } \\
\text { proteção social } \\
\text { deve ser vista no } \\
\text { sentido de } \\
\text { fornecimento de } \\
\text { cuidado ao outro } \\
\text { e não como } \\
\text { mercadoria. }\end{array}$ & $\begin{array}{c}\text { Desvincula os } \\
\text { trabalhadores de } \\
\text { uma carreira; } \\
\text { Promove 'solução } \\
\text { de continuidade' } \\
\text { nas políticas } \\
\text { públicas em longo } \\
\text { prazo; } \\
\text { Os tecnocratas } \\
\text { neoliberais } \\
\text { avançam na } \\
\text { instituição de } \\
\text { normas que } \\
\text { direcionam a } \\
\text { descontinuidade } \\
\text { de ações; } \\
\text { Inserção limitada } \\
\text { dos trabalhadores } \\
\text { terceirizados no } \\
\text { sistema por não } \\
\text { participarem } \\
\text { efetivamente das } \\
\text { representações } \\
\text { colegiadas. }\end{array}$ \\
\hline
\end{tabular}


ISSN 2179-6750

\begin{tabular}{|c|c|c|c|c|c|}
\hline Autor(es) & Tipo & Método & Reflexos no SUS & $\begin{array}{l}\text { Reflexo nas } \\
\text { políticas sociais }\end{array}$ & $\begin{array}{l}\text { Reflexos no } \\
\text { trabalhador }\end{array}$ \\
\hline & & & $\begin{array}{l}\text { - Desvincula a gestão } \\
\text { do trabalho em saúde } \\
\text { do SUS dos seus } \\
\text { preceitos; } \\
\text { - Incentiva aos } \\
\text { movimentos para } \\
\text { institucionalizar a } \\
\text { abertura para o } \\
\text { atendimento por } \\
\text { seguros privados de } \\
\text { saúde mediante } \\
\text { custeio do Estado. }\end{array}$ & & \\
\hline $\begin{array}{l}\text { Mendes Á, } \\
2011^{43}\end{array}$ & Artigo & Resenha & $\begin{array}{l}\text { Complementariedade } \\
\text { dos serviços por parte } \\
\text { da gestão pública } \\
\text { gera expansão } \\
\text { participação do setor } \\
\text { privado. }\end{array}$ & - & - \\
\hline $\begin{array}{l}\text { Carneiro } \\
\text { Junior N; } \\
\text { Nascimento } \\
\text {, VB; Costa } \\
\text { IMC, 201144 }\end{array}$ & Artigo & Ensaio & $\begin{array}{l}\text { A omissão do Estado } \\
\text { na regulação do setor } \\
\text { saúde (permite } \\
\text { avanço privado e gera } \\
\text { dependência do setor } \\
\text { público); } \\
\text { As organizações } \\
\text { sociais são } \\
\text { consideradas um } \\
\text { instrumento de gestão } \\
\text { estratégica, visa } \\
\text { mudanças no modelo } \\
\text { de gestão pública, } \\
\text { confere agilidade e } \\
\text { flexibilidade. }\end{array}$ & - & - \\
\hline $\begin{array}{l}\text { Ocké-Reis } \\
\text { CO, Sophia } \\
\text { DC, } 2009^{45}\end{array}$ & Artigo & Ensaio & - & $\begin{array}{l}\text { Projetos de } \\
\text { privatização do } \\
\text { SUS são } \\
\text { consequência das } \\
\text { restrições fiscais } \\
\text { impostas à } \\
\text { universalidade. }\end{array}$ & - \\
\hline
\end{tabular}


ISSN 2179-6750

\begin{tabular}{|c|c|c|c|c|c|}
\hline Autor(es) & Tipo & Método & Reflexos no SUS & $\begin{array}{c}\text { Reflexo nas } \\
\text { políticas sociais }\end{array}$ & $\begin{array}{l}\text { Reflexos no } \\
\text { trabalhador }\end{array}$ \\
\hline $\begin{array}{l}\text { Duarte IG, } \\
\text { Botazzo C, } \\
2009^{46}\end{array}$ & Artigo & $\begin{array}{l}\text { Pesquisa } \\
\text { qualitativa }\end{array}$ & - & - & $\begin{array}{l}\text { A terceirização de } \\
\text { gestão de pessoas } \\
\text { responde } \\
\text { adequadamente } \\
\text { ao que se espera } \\
\text { (agilidade e } \\
\text { flexibilidade na } \\
\text { contratação); } \\
\text { Problemas } \\
\text { relativos ao } \\
\text { regime estatutário } \\
\text { como: } \\
\text { - a inadequação } \\
\text { do quadro de } \\
\text { pessoal; } \\
\text { - grande } \\
\text { rotatividade de } \\
\text { funcionários por } \\
\text { transferências e } \\
\text { afastamentos, } \\
\text { baixa motivação; } \\
\text { - ausência de } \\
\text { sistema de } \\
\text { avaliação de } \\
\text { desempenho; } \\
\text { - absenteísmo; } \\
\text { - excesso de } \\
\text { pessoal com baixa } \\
\text { qualificação. }\end{array}$ \\
\hline $\begin{array}{l}\text { Amadigi } F R, \\
\text { Albuquerque, } \\
G L \\
\text { Gonçalvez ER, } \\
\text { Erdmann } A L, \\
2007^{47}\end{array}$ & Artigo & Ensaio & - & $\begin{array}{l}\text { ideologia } \\
\text { neoliberal; } \\
\text { representa um } \\
\text { retrocesso ao } \\
\text { 'bem estar social'; } \\
\text { A proteção social } \\
\text { é vista como } \\
\text { impedimento ou } \\
\text { dificuldade para } \\
\text { avanço do capital } \\
\text { financeiro; } \\
\text { As políticas } \\
\text { públicas são } \\
\text { substituídas por } \\
\text { políticas focais e }\end{array}$ & - \\
\hline
\end{tabular}


ISSN 2179-6750

\begin{tabular}{|c|c|c|c|c|c|}
\hline Autor(es) & Tipo & Método & Reflexos no SUS & $\begin{array}{l}\text { Reflexo nas } \\
\text { políticas sociais }\end{array}$ & $\begin{array}{l}\text { Reflexos no } \\
\text { trabalhador }\end{array}$ \\
\hline & & & & $\begin{array}{l}\text { compensatórias; } \\
\text { Superar a ideia de } \\
\text { um Estado } \\
\text { reduzido para que } \\
\text { se contemplem à } \\
\text { defesa da vida; } \\
\text { O fracasso do } \\
\text { neoliberalismo na } \\
\text { promoção da } \\
\text { justiça social. }\end{array}$ & \\
\hline $\begin{array}{l}\text { Barata LRB, } \\
\text { Mendes } \\
\text { JDV, } 2007^{48}\end{array}$ & Livro & Estudo descritivo & $\begin{array}{c}\text { Parceiras aumentam a } \\
\text { eficiência dos serviços } \\
\text { prestados } \\
\text { (flexibilização e } \\
\text { agilidade no contrato); } \\
\text { Balanço de suas } \\
\text { prestações de contas } \\
\text { é publicado no diário } \\
\text { oficial do Estado e } \\
\text { analisado pelo } \\
\text { Tribunal de Contas do } \\
\text { Estado (transparência). }\end{array}$ & - & - \\
\hline $\begin{array}{l}\text { Carneiro } \\
\text { Junior } N \text {, } \\
\text { Elias PEM, } \\
2006^{49}\end{array}$ & Artigo & Estudo de caso & $\begin{array}{c}\text { Ao delegar para as } \\
\text { parceiras o Estado } \\
\text { apresenta: } \\
\text { - Falta de } \\
\text { monitoramento; } \\
\text { - Não garante a } \\
\text { equidade no acesso; } \\
\text { - Não contempla o } \\
\text { controle público. }\end{array}$ & - & - \\
\hline
\end{tabular}

Quadro 1. Autores, tipo de estudo, método, reflexos da terceirização e das Parcerias Público-Privadas para o SUS, para as políticas sociais e para o trabalhador encontradas nos estudos incluídos nesta revisão. 2019 Fonte: Elaborado pelos autores (2019).

\section{Neoliberalismo, terceirização e reflexos para o sistema de saúde brasileiro}

Ribeiro $^{22}$ descreve que desde os primórdios dos governos militares, houve incentivos para expansão do setor privado, dentre eles, os autores destacam: a contratação de cooperativas médicas ou empresas privadas e discussões de políticas para privatização de serviços médicos estatais, embora existissem políticas para atendimento das camadas sociais que mais necessitavam. 
ISSN 2179-6750

De acordo com Tavares, ${ }^{37}$ o regime militar é considerado o verdadeiro precursor da privatização das políticas sociais. Com a realização da $4^{a}$ Conferência Nacional de Saúde em 1967, surge a proposta de criação do Plano Nacional de Saúde, que pretendia vender os hospitais para iniciativa privada. Mesmo com o fim do regime militar não significou a instalação de um modelo de saúde não-privatista.

Ainda, o trabalho de Tavares ${ }^{37}$ expõe que com a criação do Fundo de Apoio ao Desenvolvimento Social - FAS, as empresas de medicina passaram a contar com essa fonte de financiamento para construção, ampliação e aquisição de equipamentos. Portanto, este dado comprova que o financiamento público para o setor privado já é histórico e advém antes do SUS.

$\mathrm{Na}$ análise do contexto histórico da saúde, Araújo $^{32}$ constata o processo da apropriação privada da saúde, desde a assistência até a administração da saúde - ou seja, demonstra que o setor privado historicamente apropria-se da máquina pública, dos fundos públicos não estringindo-se apenas à assistência direta. Os direitos conquistados e inalienáveis da condição humana são submetidos ao setor privado, ao capital financeiro e, considerando que a saúde se torna nesta perspectiva "produtivista, desenvolvimentista e exploradora" abre-se espaço para a destruição da estrutura social via o direito à saúde.

Uma análise histórica da saúde pública no Brasil mostra a relação do privadopúblico e como o aparelho estatal vai incorporando-a, desenvolvendo atividades, destinando-Ihes recursos financeiros considerados. Nesta perspectiva, como apresentam os estudos até então mencionados, o predomínio da assistência médico-hospitalar privada mostra o equívoco de alguns autores que afirmam que esta se expande pós-64. Sem dúvida, neste período, observa-se uma expansão; contudo, a rede privada sempre foi dominante e privilegiada pelos regimes governamentais.

Ribeiro $^{22}$ menciona que a política do Estado de Bem Estar Social expandida na década de 1930, cujo principal objetivo era a defesa dos direitos dos cidadãos à saúde, sofreu na década de 1970 discussões sobre alguns fatores que colocaram em xeque sua condição: crise fiscal dos países, crise econômica provocada pela crise do petróleo em 1973 e o inconformismo dos contribuintes que não viam a melhora dos serviços públicos apesar dos tributos. Segundo a autora, ${ }^{22}$ por este motivo, o Banco Mundial, já estipulava que era preciso alcançar novos mecanismos de políticas públicas que não distorcessem a alocação de recursos.

Assim, foi neste caminho no qual se abriu espaço no Brasil para justificação do modelo gerencial da administração pública. Este modelo passou a ser fruto das pressões externas (internacionais) e também na tentativa de atrair a iniciativa privada para se ter investimentos em novas estruturas, e em políticas públicas e sociais. ${ }^{22}$ Não obstante, no 
ISSN 2179-6750

Brasil, Albuquerque et al. ${ }^{28}$ descrevem que, em plena conjuntura neoliberal, a partir da década de 1990, o governo Fernando Henrique Cardoso, incentivou a tendência de privatização do SUS por meio das contratualizações, atendendo, desta forma, os interesses privados.

O modelo neoliberal de se repensar o papel da saúde, de acordo com Castro, ${ }^{33}$ contempla os seguintes pontos: i) a delimitação do tamanho do Estado; ii) a redefinição do papel regulador do Estado; iii) a recuperação da governança ou capacidade financeira e administrativa de implementar as decisões políticas tomadas pelo governo; e iv) o aumento da governabilidade ou capacidade política do governo de intermediar interesses, garantir legitimidade, e governar.

O antagonismo ao pensamento neoliberal, conforme defendido por Lara et al. ${ }^{26}$ vem dos ideais da Reforma Sanitária em assumir uma batalha para separar o público do privado, defendendo que o público é referente a tudo aquilo que é de interesse coletivo e de responsabilidade do Estado, ou seja, definir os papéis entre o público e o privado, na medida que o público é relativo ao Estado com interesse em atender os direitos sociais e o privado a do mercado. Os próprios autores ${ }^{26}$ concluem e defendem estilos de vida que privilegiem as necessidades comuns da população e não as demandas e interesses de mercado.

Com a política de reforma do Estado, dentro do contexto neoliberal, na defesa da construção de um Estado mínimo, o Estado tem a função de regular os serviços, até mesmo do setor privado. ${ }^{22,26}$ Contudo, conforme aponta Castro, ${ }^{33}$ a justificativa, para a reforma nos sistemas de saúde não estava pautada na crise do contexto neoliberal, mas sim nos altos custos da assistência médica gerando um crescimento dos gastos com saúde.

Castro, $^{29}$ destaca ainda, que os desafios do sistema de saúde encontram-se na necessidade de maior eficiência na prestação de serviços de saúde, por meio do controle de prestadores de serviços e produtores do setor; na utilização de avaliações no processo de incorporação tecnológica e de produtos em saúde, bem como da normatização de condutas, e nas formas de remuneração e contratação de prestadores e, sobretudo, discutindo a ineficiência do Estado.

Já Travassos, ${ }^{41}$ discorda e coloca que a privatização do cuidado da saúde representa uma ameaça dos direitos conquistados e a falta de regulação caminha com a crescente comercialização e de modo dissimulado. Nesse cenário é possível compreender porque o aumento dos preços, a ineficiência, os abusos e a incapacidade de atender as necessidades de saúde de uma maneira geral ${ }^{41}$ apareçam como argumentos para terceirizar os serviços. 
ISSN 2179-6750

O processo de descentralização do SUS na década de 1990, aliado a possibilidade dos gestores em contratar prestadores filantrópicos privados, fomentou a terceirização. ${ }^{22}$ Não devemos nos esquecer da Lei de Responsabilidade Fiscal em 2000, que ao limitar a contratação de pessoal pelo serviço público acelerou o processo de terceirizar os serviços. Considerando este cenário, Lara et al., ${ }^{26}$ argumentam que a ideia central é normalizar a vida por meio dos interesses mercantis, em outras palavras, os direitos sociais da população apresentam o manejo seguindo os interesses do mercado.

Lara et al., ${ }^{26}$ ainda destacam que o pensamento neoliberal não tem como objeto o fortalecimento de um Estado que se efetivem os direitos sociais declarados na Constituição de 1988 e sim seu entendimento dentro de uma lógica que interesse a sua garantia. Dentro dessa linha de raciocínio, para o pensamento neoliberal, a relação entre o público e privado é necessária para progredir na qualificação do setor de saúde. ${ }^{26}$

Com o avanço do neoliberalismo, de acordo com Melo e Lessa, ${ }^{24}$ há recorrência ao fundo público como garantidor a priori do lucro burguês que se manifesta nos processos de privatização. Temos os contratos que favorecem entes privados, além das PPP e da ampliação de programas de isenção e/ou renúncia fiscal.

Alguns autores, ${ }^{44,47}$ ao versarem sobre a proposta de reforma do Estado brasileiro, consideram as organizações sociais um instrumento de gestão estratégica válida para as mudanças necessárias do modelo de gestão pública, pois defendem que estas conferem agilidade e flexibilidade para o setor público.

As organizações sociais, de acordo com Araújo, ${ }^{32}$ surgiram no Brasil como instrumento de viabilização e implementação de políticas públicas, de acordo com o Plano Diretor da Reforma do Aparelho do Estado. Aprovou-se no Congresso Nacional a Lei n. 9.637/1998, que "dispõe sobre a qualificação de entidades como organizações sociais, a criação do Programa Nacional de Publicização". As OS podem, assim, contratar funcionários sem concurso público, adquirir bens e serviços sem processo licitatório e não prestar contas a órgãos de controle internos e externos da administração pública porque estas são consideradas atribuições privativas do Conselho de Administração, e ainda podem aprovar por maioria, no mínimo, de dois terços de seus membros, o regulamento próprio contendo as normas e regras que deve adotar para a contratação de obras, serviços, compras e alienações e o plano de cargos, salários e benefícios dos empregados.

Barreto et al. ${ }^{25}$ definem, parcerias público-privadas, como aquelas regulamentadas pela Lei Federal n. 11.079, de 30 de dezembro de 2004. Seriam como contratos de parcerias firmados entre o setor público e o setor privado, em que o parceiro público contrata o parceiro privado para execução de serviços ou empreendimentos públicos, sendo remunerado pelos serviços prestados. Entende-se como uma espécie de concessão 
ISSN 2179-6750

do público para o privado, ou seja, nada mais é do que um contrato de serviço de que a administração pública é usuária direta ou indireta, não envolvendo cobrança direta ao usuário, no qual a remuneração do parceiro é de responsabilidade exclusiva do ente público

Araújo $^{32}$ expõe que a terceirização e a privatização da saúde se transformam em problemas previsíveis e isso a própria história do Brasil demonstra, destacando a transferência da "poupança pública" para o setor privado e lucrativo, repassando patrimônio, bens e serviços e dotação orçamentária pública para empresas de direito privado, além de incitarem o fim do concurso público, comprometendo o sistema de referência e contra referência e a hierarquização dos serviços de saúde.

É importante ressaltar que todo este debate se relaciona à chamada criação do "terceiro setor". Este seria um campo de intensa atividade econômica indo além do campo da desinteressada filantropia. Embora sejam entidades ditas "sem fins lucrativos", as OS não escondem seus interesses lucrativos, de acordo com Contreiras e Matta. ${ }^{31}$

Melo e Lessa ${ }^{24}$ colocam, no atual contexto, que a política de saúde brasileira com a crescente influência neoliberal passa a sofrer ataques, devido a sua intensa mercantilização, negação e retração dos serviços e direitos, desfinanciamento, privatização e terceirização. Assim, a própria omissão do Estado na regulação do setor saúde permitiu o avanço do setor privado e cada vez mais a dependência do setor público. ${ }^{33,44}$

As contratualizações entre o público e o privado na área da saúde, tende a ocorrer por caminhos tortuosos, obscuros e burocráticos dentro de um estado hegemonizado por forças sociais de interesses privados, conforme descrito no trabalho de Albuquerque et $a l^{28}$ Os autores ${ }^{28}$ alertam que se têm visto várias relações entre o Estado e parceiros privados: PPP, OSCIP, OS, na tentativa de garantir a continuidade da assistência à saúde e ideias de apoio a reforma sanitária defendem que isso significa sua mercantilização. Essas parcerias, terceirizações ou privatizações do serviço público envolvem transferências de bens públicos, recursos humanos e financeiros para o setor privado, sob o argumento de precarização dos vínculos e dos recursos humanos. Neste sentido, deve-se ponderar os interesses entre o público e o privado.

A terceirização está num avanço crescente na atual realidade e o Estado ao atuar no planejamento, supervisão, regulação dos serviços, avaliação, corre o risco de deterioração da qualidade dos serviços prestados, conforme exposto por Albuquerque et al. ${ }^{28}$ Assim, ao se analisar a participação do setor privado garantido na Constituição Federal de 1988 em caráter complementar, pode-se dizer que o papel do Estado pode ficar comprometido como garantidor dos direitos à saúde, isto porque, da maneira como está ocorrendo, o 
caráter complementar da iniciativa privada passa a ser substitutivo, ou seja, o público se retira dando lugar para a atuação do privado.

Mendes, ${ }^{34}$ destaca que se torna dificultoso a utilização da complementariedade dos serviços por parte da gestão pública em decorrência da expansão muito além da participação do setor privado conforme previsto na Constituição Federal de 1988. Já Castro $^{33}$ chama atenção ao fato de se fazer necessário o fortalecimento da regulação pública sobre os diferentes arranjos público-privados de forma a fortalecer os princípios e diretrizes do SUS.

Romano e Scatena ${ }^{39}$ concordam com a complementação do setor público pelo privado na saúde, mas, entendem que as falhas no processo de regulação do setor privado sugerem uma crescente e descontrolada participação deste setor na saúde, e, com isso, passa a possuir expressivo poder político e de pressão no que se refere a negociação ou intermediação de seus contratos, bem como a remuneração de serviços prestados.

Ainda, Romano e Scatena ${ }^{39}$ reiteram que a saúde privada tem que conviver com a pública, mas, acima de tudo é necessário uma regulação eficiente. Reitera-se ainda que dentro do contexto de maior agilidade nos serviços e resolutividade para os usuários, destaca-se problemas ou distorções importantes ainda por esse modelo ofertado sob regime ambulatorial. Como exemplo, tem-se a seleção da demanda por enfermidades que resulta em procedimentos melhor remunerados segundo a tabela SUS, o excesso de pedido de consultas com outros especialistas, exames complementares, muitas vezes, sem necessidade.

Ribeiro $^{22}$ destaca que a saúde não pode estar desvinculada do Estado cujo papel é assegurar os direitos. Ao vincular a saúde às regras mercantis, mesmo o serviço prestado pelo setor privado, ainda assim o serviço deve ser regulado pelo Estado e nessa ideia, defendida por Ribeiro, ${ }^{22}$ se evita a mercantilização da saúde. Mas a mercantilização da saúde, dentro do contexto das parcerias e terceirizações, sempre estará presente, pois além de estar preconizada constitucionalmente, há construção de uma narrativa de descrédito do público em favor do privado. ${ }^{42}$

Castro $^{29}$ aponta para o fato se a existência do privado se justificaria na organização dos prestadores privados, especificamente para preencherem as lacunas assistenciais do SUS. Contudo, com seu avanço, a lógica dos interesses privados e de mercado passa a moldar e afetar as decisões no âmbito da gestão pública como, também, agravando a segmentação da clientela, na medida em que se observam diferenciações quanto à qualidade e tipo de serviço de saúde disponível.

Machado ${ }^{48}$ faz uma citação de Lígia Bahia, que afirma que as relações entre público e privado se tornaram cada vez mais entrelaçadas, resultando em uma estratificação tão 
complexa na oferta e, também, na utilização de serviços de saúde que hoje em dia, exigese um esforço político enorme para desfazer este processo. O argumento central é que essas características da intensa mescla público-privado travam a plena implementação de políticas universais na saúde.

Sobre este ponto, Borges ${ }^{42}$ expõe que esta mescla é assentada nas diferentes formas em que o contrato de prestação de serviço é consagrado, já que este contrato não é um contrato de gestão propriamente dito mas, a depender da modalidade de terceirização, há diversas formas de concessão que delimitam um número intenso de matizes ou gradações desta mescla. Contudo, o autor ${ }^{42}$ reafirma que, considerando que o órgão financiador das OS é o Estado, o poder da gestão continuaria sob o aval do público estatal, pois este deteria a direcionalidade no campo da formulação de políticas de saúde.

Barata e Mendes ${ }^{48}$ avaliam que as OS do Estado de São Paulo, campo de sua investigação, levam ao aumento da eficiência dos serviços prestados devido a maior flexibilização e agilidade na contratação de pessoal e que o balanço de suas prestações de contas é publicado no diário oficial do Estado e analisado pelo Tribunal de Contas, sendo este um dos caminhos encontrados para aperfeiçoar a prestação de serviços pelo SUS.

Por outro lado, ao se valer da mesma experiência de São Paulo, Contreiras e Matta ${ }^{31}$ afirmam que a administração gerencial, estabelecida pelo setor privado nos serviços de saúde, está longe de cumprir a eficiência que por sua definição exige um controle financeiro estrito. Segundo Contreiras e Matta $^{31}$ o processo de reforma do Estado, no plano social, foi proposto à delegação dos serviços públicos para entidades "sem fins lucrativos" que na época foram alvos de críticas por parte dos movimentos sociais e parlamentares. Em São Paulo, a terceirização da saúde foi muito acentuada, sendo que em 2010, 96\% dos estabelecimentos de saúde estavam sob gestão privada com destaque para a falta de regulação das entidades conveniadas que permaneceram durante anos, tornando-se invisíveis diante da fiscalização do judiciário e legislativo.

Para Romano e Scatena ${ }^{39}$ a eficiência e o bom desempenho não são particularidades exclusivas dos setores privados ou público. $O$ trabalho de Borges ${ }^{42}$ descreve que os sistemas públicos de saúde possuem melhores desempenhos, por não possuírem compromisso com os dividendos e por estabelecerem melhores condições de trabalho e salário, desprovendo os interesses que mediam acesso ao sistema e ainda preocupam-se na realização de atividades de promoção à saúde dentre outras.

Carneiro Júnior e Elias ${ }^{49}$ levantam a forma como o Estado brasileiro tem delegado a assistência para entidades privadas através das organizações sociais. Eles afirmam que esta delegação não atende a efetivação do controle público e a própria equidade do acesso aos serviços. Reforçam que a questão central se encontra na capacidade do Poder Público 
em estar presente na implementação dessa modalidade de gestão no âmbito local, retendo e ao mesmo tempo ampliando o espaço para formulação de política. É necessário considerar que o monitoramento destes contratos de gestão não é uma tarefa das mais fáceis, com diversas falhas apontadas nos mecanismos de controle de contratos e gestão.

Leite $^{38}$ levanta questões sobre as avaliações realizadas acerca da eficiência das organizações públicas e provadas. Para a autora, não existem avaliações confiáveis que demonstrem maior eficiência das organizações prestadoras de serviços, assim como que as avaliações de resultados ainda padecem de diversos problemas como, por exemplo, a manipulação de resultados de acordo com "metas conservadoras" estabelecidas pela própria gestão. Afirma ${ }^{38}$ ainda que instrumentos de gestão flexíveis não garantem a transparência e eficiência do serviço. A contratualização, segundo a autora, não é garantia de melhor desempenho e que os resultados satisfatórios dependem de uma organização institucional que assegure o enfrentamento do problema da assimetria de informação para que se possa monitorar melhores seus resultados.

De acordo com Albuquerque et al., ${ }^{28}$ o problema da mensuração da eficiência e do desempenho destas terceirizações reside na questão da falha no controle externo e sem a participação da sociedade civil organizada. Feitosa e Montenegro ${ }^{27}$ assinalam, por exemplo, que a monitorização dos custos em geral nestas instituições privadas se orienta pela expectativa de sua redução. Isto, em saúde pode estar mais sujeitos a fraudes, seja pela má avaliação dos chamados "custos escondidos", pelos "custos indiretos" ou ainda pelos "custos sociais".

Albuquerque et al. ${ }^{28}$ complementam que esta questão está ligada a contratualização de redes isoladas. Ao desconsiderar que o SUS se organiza por redes e linhas de cuidado em diferentes escalas geopolíticas, há a tendência de se fugir da lógica do sistema e de dificultar o mecanismo de implantação de estruturação das redes. Os autores ${ }^{28}$ afirmam que o projeto de terceirização não consegue fazer oposição aos interesses do capital e como consequências deixa lacunas no cumprimento do contexto público.

Albuquerque et $a l^{28}$ ainda apontam que, na cidade de Recife, há predomínio público estatal na atenção ambulatorial básica e o privado na atenção hospitalar recebendo maior repasse. Os secretários defendem o processo de contratualização como meio de garantir a condução da gestão pública e de aumentar a capacidade organizacional da rede. Dentre alguns secretários entrevistados, destacam a questão que a concentração de leitos por algumas especialidades não tem sido determinada pela necessidade de saúde dos usuários. Afirmam ainda que os secretários de saúde se mantem refém dentro de um sistema moldado nos privilégios acumulados pelo setor privado, 
ISSN 2179-6750

como se the faltasse poder público para assegurar uma oferta que atenda às necessidades. ${ }^{28}$

Outra questão colocada na literatura, apontada por Rodrigues e Spagnuolo ${ }^{35}$ está relacionada às vantagens das parcerias na aquisição mais rápida de materiais e equipamentos. Isto está de acordo com a tese realizada por Borges. ${ }^{42} \mathrm{O}$ autor $^{42}$ relata vantagens e desvantagens na contratação das OS. Dentre os pontos positivos destacou a agilidade na compra de bens, maior autonomia na gestão do trabalho em saúde, sistema de metas que permitiria melhor avaliação de desempenho. Do ponto de vista negativo, afirma a não submissão às leis das licitações levando a seleção das OS de maneira simplificada, fragmentação do sistema à medida que fica estabelecido o duplo comando, regulação por mecanismos alheios ao SUS, ocupação de estruturas estatais por prestadores de serviços privados, desvinculação da gestão do trabalho em saúde do SUS, incentivo aos movimentos para institucionalizar a abertura para o atendimento por seguros privados de saúde mediante custeio do Estado.

Rodrigues e Spagnuolo ${ }^{35}$ concordam com o argumento da maior agilidade na aquisição de bens e mão de obra com o processo de terceirização, por outro lado, defendem a necessidade de aprimorar os mecanismos de controle que garantam maior transparência, do qual necessita da eficiência do Estado fiscalizador.

Nota-se que o próprio sistema de informática apresenta limitações para demonstrar essa transparência no decorrer dos contratos de gestão. Por sua vez, é destacado por Rodrigues e Spagnuolo ${ }^{35}$ que os Conselhos Curadores são o órgão máximo das OS, com funções deliberativas, fiscalizadoras e normativas, mas historicamente a participação social é bem restrita e pouco efetiva, pois também ocorre o distanciamento da população devido seu caráter burocrático e hierárquico.

A transparência social também foi exposta, na defesa de que esta deve estar presente em todas etapas da contratualização com as OS, conforme afirma Silva. ${ }^{36}$ Os resultados da pesquisa de Silva ${ }^{36}$ apontam para dificuldades de monitoramento dessas etapas no município do Rio de Janeiro, alegando que apenas o edital é publicado no Diário Oficial e até mesmo as avaliações dos contratos de gestão, não são divulgados pela secretaria, sendo apenas encaminhadas para avaliação interna. Desta forma, o Estado não apresenta ferramentas regulatórias necessárias, dificultando o processo de avaliação dos serviços prestados.

Silva ${ }^{36}$ afirma ainda, que as OS, sendo consideradas uma ferramenta na aquisição de bens e serviços, estabelece-se uma relação de subordinação com limitação de inovações gerenciais. $O$ estabelecimento das metas contratuais também foi muito bem apontada por Silva $^{36}$ quando destaca que o desafio não é torná-las apenas um instrumento de 
cobranças, pois isso limita a capacidade de inovação, criatividade, tornando uma assistência focal.

Outro destaque neste sentido é aquele descrito por Paulus Júnior. ${ }^{40} \mathrm{O}$ autor discute que o processo de contratualização deve ir além do estabelecimento de metas, que inclusive devem ser claras e decorrentes de dados históricos e epidemiológicos, como também deve envolver, de forma coordenada, a integração dos diversos serviços. $O$ contrato de gestão deve ser negociado, com a participação dos trabalhadores, analisa Paulus Júnior. ${ }^{40}$ Caso isto não ocorra corre-se um grande risco de direcionar uma assistência fragmentada na elaboração das metas contratuais nos serviços terceirizados.

Os mecanismos de avaliação das OS ou de seus contratos de gestão, conforme coloca Leite ${ }^{38}$ não devem ocorrer apenas pelo cumprimento das metas e da adesão dos indicadores, mas deve ser contextualizada no âmbito da implantação do SUS, como adesão a seus princípios básicos. Há necessidade de aperfeiçoamento dos mecanismos de fiscalização do terceiro setor com priorização de fiscalização em áreas específicas, desburocratização dos meios de investigação e estabelecer novos fluxos de informação através de sistemas informatizados.

Paulus Júnior ${ }^{40}$ aponta falhas no processo de monitoramento destes contratos, alegando existir dificuldades em efetuar um monitoramento adequado em prazos úteis, além da falta de prioridade na operacionalização das comissões de avaliação e geralmente as secretarias contam com pouca estrutura na execução desta função.

Por fim, Barreto et al. ${ }^{25}$ relatam uma experiência bem sucedida envolvendo a parceria público-privada no Hospital de Subúrbio na Bahia, acreditado pleno pela ONA (Organização Nacional de Acreditação) em 2015. A gestão é transparente, demonstrada pela publicização dos indicadores assistenciais por meio de aplicativo e disponibilizado nas plataformas Android e IOS, contribuindo para transparência necessária do serviço público.

\section{Políticas sociais diante do contexto neoliberal e das terceirizações na saúde}

As políticas macroeconômicas levam a diminuição dos gastos públicos na saúde, por exemplo, tornando preocupante o processo de aumentar os riscos de "desuniversalização" gerando uma diminuição assistencial das políticas sociais conforma aponta Mendes. ${ }^{34,43}$

O SUS é um dos maiores sistemas públicos de saúde. Contempla desde a atenção básica até serviços de média e alta complexidade, os serviços de vigilância em saúde e a gestão propriamente dita. Torna-se muito preocupante os projetos de privatização do SUS 
mediante as restrições fiscais impostas à universalidade do acesso e de sua integralidade e consequente privatização do sistema público. ${ }^{42,45}$

A ideologia neoliberal, segundo Amadigi et al., ${ }^{47}$ representou um retrocesso à origem do bem estar social. Neste contexto, a proteção social atribuída ao Estado é vista como impedimento ou dificuldade para avanço do capital financeiro e dentro dessa concepção as políticas públicas seriam substituídas por políticas focais e compensatórias. Dentro deste cenário, o Estado continua destinando seus recursos, mas, não para ampliação de sua rede de serviços, e sim para terceiros. Essas propostas, com pouco investimentos em políticas sociais aumentam ainda mais o número de vulneráveis.

Amadigi et al. ${ }^{47}$ ainda citam que se deve superar a ideia de um Estado reduzido, e pensar eticamente sobre a organização e o papel do SUS para consolidar políticas públicas que contemplem a defesa da vida. Uma das formas características da atuação estatal de caráter privado para delegar a execução das políticas sociais é através da chamada terceirização, segundo Melo e Lessa. ${ }^{24}$ Para esses autores, a legislação brasileira abriu espaço a isto em função de sua sintonia com os projetos neoliberais defendidos pelo Banco Mundial.

A política de saúde tem sido capturada cada vez mais pelos interesses do capital: o lucro nas políticas de saúde tem sido um fértil campo para o terceiro setor dentre os quais se destacam: a mercantilização e a ampliação da capitalização das políticas sociais. ${ }^{24}$ Como asseveram Campos et al., ${ }^{29}$ dentro do modelo neoliberal e privatista em curso, a geração de políticas sociais paliativas são produzidas em substituição às políticas estruturais.

Melo e Lessa ${ }^{24}$ apontam que ao longo dos anos 2000 foram aprovadas várias legislações que regulamentavam as OS nos Estados como forma de terceirização. Mesmo no governo pelo dito Partido dos Trabalhadores as condições de saúde apresentaram-se frágeis. Foram desenvolvidas políticas sociais sob a lógica econômica, focalizada na pobreza e dotadas de baixo financiamento. O Programa de Saúde da Família que se ampliou em 1995 nas grandes metrópoles do país passou a ser executado com o suporte de entidades privadas como no caso das Clínicas da Família no Rio de Janeiro que são geridas por OS e destas, $80 \%$ estão sob investigação do Ministério Público.

A política de saúde é dotada de muitas interfaces com outras políticas e como direito social faz parte integrante da Seguridade Social e como condição individual e coletiva não deve ser submetida às condições mercantilistas e do capital. Mesmo não havendo venda de serviços, o caso do modelo da Fundações e Associações sem fins Lucrativos - FASFIL configura-se claramente uma privatização das políticas sociais como um todo. ${ }^{24}$ 
ISSN 2179-6750

Melo e Lessa ${ }^{24}$ destacam ainda que a falta de transparência na execução da política de saúde e o superfaturamento das ações soma-se a pretensão de ampliar a participação do setor privado na formulação de políticas nacionais de saúde. ${ }^{35}$ Scheffer $^{26}$ também considera que a participação do capital estrangeiro na saúde foi fruto da vitória envolvendo os interesses de hospitais privados, da indústria farmacêutica e planos de saúde.

A rigor esses estudos se inserem no quadro dos anos pós-1990 em que se adentra num ambiente contrarreformista. Isto significa que as reformas preconizadas para as políticas públicas, em geral, e para a saúde em particular, foram bastante orientadas para o mercado, num contexto em que os problemas no Estado brasileiro eram indicados como causas centrais da ampla crise econômica e social experimentada pelo país desde o início dos anos 1980. Reforma-se o Estado, com ênfase nas privatizações, desprezando as conquistas de 1988 no âmbito da seguridade social, principalmente.

A saúde pública enxerga a saúde como um bem bastante diferente das mercadorias produzidas, razão pela qual se deveria reservar a mesma um tratamento específico, inclusive em termos de proteção, encarada como um bem comum. Segundo Amadigi et al., ${ }^{47}$ é possível entender o fracasso do neoliberalismo na promoção da justiça social. Isso porque seu sentido está diretamente vinculado ao mercado financeiro e, por sua vez, não poupa o mais fraco, como por exemplo na fragilização nas relações de trabalho.

\section{O trabalhador diante do contexto neoliberal e das terceirizações na saúde}

Duarte e Botazzo ${ }^{46}$ descrevem que o regime de terceirização de gestão de pessoas, por exemplo as OS na área da saúde, respondem adequadamente ao que se espera do modelo nos quesitos de agilidade e flexibilidade nos processos de contratação. Argumentam ainda que, conforme relatório emitido pelo Banco Mundial, problemas relativos ao regime estatutário como: a inadequação do quadro de pessoal, grande rotatividade de funcionários por transferências e afastamentos, baixa motivação, ausência de sistema de avaliação de desempenho, absenteísmo, excesso de pessoal com baixa qualificação, constituem problemas que podem ser eliminados com a terceirização.

Num estudo de caso único do Município de Botucatu-SP, realizado por Rodrigues e Spagnuolo ${ }^{35}$ partindo dos membros de conselho de Curadores da Fundação UNI, aponta que por limitação da LRF, foi instituído convênio com entidade filantrópica para gestão em saúde, destacando maior agilidade na forma de egresso dos trabalhadores, o que, segundo os autores parece algo positivo para justificar a terceirização. 
Já na contra-argumentação destacamos a seguir alguns trabalhos sobre esse modelo adotado.

Primeiramente, é pertinente lembrar que todos os problemas apontados pelo Banco Mundial no regime estatutário também acontecem no modelo de terceirização.

Borges $^{37}$ demonstra que a gestão do trabalho na saúde terceirizada apoia-se na desvinculação dos trabalhadores de carreira, ou seja, aqueles que formam a massa crítica do SUS. Esta desvinculação promove certa "solução de continuidade" às políticas públicas de longo prazo. Essa massa crítica passa a ser fragmentada, onde se instituem "rachaduras" irreparáveis nas ações de longo prazo em saúde pública. A partir dos efeitos dessas "rachaduras", os tecnocratas neoliberais avançam na produção de normas que direcionam a descontinuidade de ações e fomentam o espaço para a inserção de interesses privados e o desenvolvimento da privatização de serviços públicos de saúde.

Ribeiro $^{22}$ destaca algumas desvantagens no processo de terceirização, no qual descreve:

(1) Gestão de contratos: O poder público deve fiscalizá-los, e isso requer mais mão de obra e pessoas especializadas, com a finalidade de fiscalizar o cumprimento das leis trabalhistas, metas, o que demanda a criação de um departamento específico para isso e maiores custos;

(2) Rescisão: A contratada sofre desembolso mais vultoso devido as verbas rescisórias, trabalhadores ingressam com ações trabalhistas pleiteando benefícios ou direitos que poderão ser arcados pela própria administração já que responde subsidiariamente;

(3) Controle de encargos previdenciários: sonegações podem ocorrer no recolhimento das contribuições previdenciárias. A contratada pode apresentar a documentação à fiscalização e alterar as informações à Receita e pode também não recolher os valores e informar à Administração que realizou a compensação de valores retidos;

(4) Recolhimento do Fundo de Garantia por Tempo de Serviço - FGTS: Nada impede que essa documentação seja apresentada de forma fraudulenta pela empresa contratada.

Além do mencionado, outro problema apontado por Ribeiro ${ }^{22}$ refere-se ao fato de que a terceirização leva a maior rotatividade no trabalho causando impacto no tempo de vínculo empregatício e podendo gerar insegurança, menor remuneração, incertezas em conseguir novo emprego em pouco espaço de tempo, impacto na aposentadoria, despesa do Estado com os seguros desempregos devido a alta taxa de rotatividade destes trabalhadores e ameaças aos direitos trabalhistas. 
ISSN 2179-6750

Pode ainda dizer que esses setores tendem a contratar muitas "indicações" de pessoal, descomprometendo-se com a qualidade e a eficiência prometida pelo setor privado. 22,24

Melo e Lessa ${ }^{24}$ defendem o SUS público, efetivamente financiado capaz de prover atenção integral com trabalhadores concursados com plano de carreira. É importante dizer que o SUS tem incorporado importante número de trabalhadores terceirizados com mecanismos de seleção de pessoal questionável e sem grandes perspectivas de crescimento na carreira, permanecendo os vínculos trabalhistas de curta duração e com menos direitos e com isso coloca em xeque a lógica do aprendizado permanente, com vistas ao atendimento qualificado. ${ }^{24}$

Feitosa e Montenegro ${ }^{27}$ relatam outra questão. Estes apontam para a segmentação dos trabalhadores e sua perda da força social, gerando a fragilização das lutas coletivas e aliados a perda das forças sindicais, insegurança frente ao emprego, o aumento do ritmo de trabalho e as crescentes exigências voltadas para a máxima produtividade.

Outra consequência do processo de terceirização, segundo Feitosa e Montenegro ${ }^{27}$ consiste na transferência de responsabilidades do campo do direito do trabalho para o direito civil. As questões trabalhistas passam a ser tratadas entre duas empresas (a contratante e a contratada) e não mais entre a organização e o trabalhador, além de contribuir para o processo contínuo de exclusão social, demonstrada tanto pela redução de postos de trabalho e de salários, quanto pela perda de direitos e garantias trabalhistas fundamentais para o trabalhador, além de considerar um processo de vulnerabilidade social e insegurança frente ao futuro.

Campos et al. ${ }^{29}$ discutem o aumento na busca pela produtividade, a corrosão dos direitos trabalhista, contratos temporários, aumento do tempo para aposentadoria e acima de tudo fomenta a importância das pressões sociais para que possa promover o recuo da ofensiva neoliberal e a alerta que as instituições sociais precisam formar trabalhadores críticos, capazes de reconhecer os mecanismos de alienação, ter capacidade de criticar políticas públicas de saúde e denunciar esses males que o sistema impõe.

No trabalho de Araújo $^{32}$ levantam-se os problemas relativos à terceirização dos recursos humanos pelas OS e OSCIP, culminando com a desorganização do trabalho em saúde, flexibilização dos contratos, precarização do trabalho e o comprometimento da hierarquização na saúde, à medida que cada serviço privado tem seu escalão administrativo.

Castro $^{33}$ mostra a preocupação do vínculo de profissionais na Estratégia da Saúde da Família, principalmente em destaque para o médico. Entende que a alta rotatividade prejudica a própria eficiência do setor primário principalmente na criação de vínculo com a 
ISSN 2179-6750

população. Isto corrobora com Borges ${ }^{42}$ quando este se refere à inserção limitada dos trabalhadores terceirizados no sistema, por não participarem efetivamente das representações colegiadas, como por exemplo, as Conferências de Saúde.

De forma geral, observa-se por meio dos estudos mencionados, que o trabalhador na saúde vem padecendo de sofrimentos diante das condições de precarização, desorganização e intensidade do trabalho no âmbito do avanço do neoliberalismo. Devese, ainda, articular muito bem essa degradante situação do trabalho em saúde com as transformações contemporâneas do modo de produção capitalista e de suas relações com a forma Estado no nosso país.

\section{Conclusão}

A expansão das terceirizações e parcerias público-privadas na área da saúde representam sua mercantilização, à medida que os contratos permitem negociar assuntos de interesse do privado. Aliado a isso, tem-se a fragilidade da regulação do Estado nas mais diversas formas de privatização da saúde, proporcionando uma expansão do setor privado, não mais de caráter complementar como previsto na Constituição de 1988, mas sim substitutivo.

Foi possível constatar que as terceirizações ameaçam os direitos sociais conquistados, se constituem em importantes ferramentas que se contrapõem à proteção social atribuída pelo Estado, permitindo o avanço da política e ideais neoliberais.

A análise geral dos estudos permitiu identificar várias desvantagens das terceirizações, sintetizadas nos seguintes aspectos: a mercantilização em função dos ideais neoliberais, a crítica sobre a agilidade e eficiência que está longe de ser alcançada, a fragmentação do sistema, problemas de regulação, falta de transparência, falhas de monitoramento, problemas no estabelecimento de metas fixas, limites à inovação e criatividade, alta rotatividade profissional e impacto sob o vínculo empregatício.

Sobre as vantagens apresentadas nas terceirizações observou-se um número menor de aspectos, que podem ser resumidos como a agilidade e flexibilidade na contratação de pessoal.

Como visto, há uma vasta gama de reflexões acerca das parcerias público-privadas e terceirizações. Desta forma, esperamos contribuir para o debate e trazer como proposta futuras discussões, à medida que muitas considerações levantadas devem ser analisadas e ajustadas. Nesta perspectiva, confirmamos a hipótese desta pesquisa, que dentro da atual conjuntura neoliberal, com consequente expansão desenfreada das parcerias público- 
privadas e terceirizações na área da saúde, criam-se muitos problemas para o sistema de saúde, trabalhadores e para a própria prática das políticas sociais.

\section{Referências}

1. Bartolomei EFB, Carvalho MS, Delduque MC. A saúde é um direito!. Saude Debate. 2003;27(65):184-91.

2. Brasil. Lei n. 8.080, de 19 de setembro de 1990. Dispõe sobre as condições para a promoção, proteção e recuperação da saúde, a organização e o funcionamento dos serviços correspondentes e dá outras providências. Brasília, DF: Diário Oficial da União; 1990 [citado 13 out. 2018]. Disponível em: http://www.planalto.gov.br/ccivil_03/leis/L8080.htm.

3. Bresser-Pereira LC, Wilheim J, Sola L, organizadores. Sociedade e estado em transformação. São Paulo: UNESP, 1999.

4. Ministério da Saúde (BR). Portaria n. 1034, Dispõe sobre a participação complementar das instituições privadas de assistência à saúde no âmbito do Sistema Único de Saúde. 2010 [citado 13 out. 2018]. Disponível em: http://bvsms.saude.gov.br/bvs/saudelegis/gm/2010/prt1034_05_05_2010_rep.html.

5. Mendes LCA. Estado e terceiro setor: uma análise de aproximação. Rev Serv Publico. 1999;5(3):72-91. https://doi.org/10.21874/rsp.v50i3.352

6. Santos A. Privatização, terceirização e parceria nos serviços públicos: conceitos e tendências. [São Paulo: Instituto Pólis]; 5 jan. 2009 [citado 14 out. 2018]. Disponível em: http://www.polis.org.br/uploads/509/509.pdf.

7. Correia MVC, Santos VM. Privatização da saúde via novos modelos de gestão: as Organizações Sociais em questão. In: Bravo MIS, Andreazzi MFS, Menezes JSB, Lima JB, Souza RO, organizadores. A mercantilização da saúde em debate: as organizações sociais no Rio de Janeiro. 1a ed. Rio de Janeiro: UERJ; 2015. p. 33-41.

8. Salama P. L'etat et ses particularités dans les pays émergents latino-américains: une approche théorique a partir de l'ecole de la dérivation. In: Artous A, Salama P, Solís González JL, Tran HH. Nature et forme de l'etat capitaliste: analyses marxistes contemporaines. Paris: Editions Syllepse; 2015. p. 125-52.

9. Bravo MIS. Política de saúde no Brasil: reforma sanitária e ofensiva neoliberal. 3. Seminario Internacional de Derechos Humanos, Violencia y Pobreza: la situación de los niños y 
adolescentes en América Latina hoy; [s.f. citado 13 out. 2018]; Guayaquil, Equador. Santiago de Guayaquil: Universidade Católica. Disponível em: http://www.ts.ucr.ac.cr/binarios/congresos/reg/slets/slets-019-187.pdf.

10. Marques RM, Ugino CK. O Brasil é chamado à ordem. Argumentum. 2017;9(3):8-23. https://doi.org/10.18315/argum.v9i3.17944.

11. Machado TTL, Santana TLT. A privatização da saúde e a contrarreforma do estado: o processo de desmonte dos direitos sociais. 2. Congresso Internacional de Política social e serviço social: Desafios contemporâneos. 3. Seminário nacional de território e gestão de políticas sociais. 2. Congresso de direito à cidade e justiça ambiental (política social, seguridade social e proteção social); 4-7 jul. Londrina PR, de 04 a 07 jul. 2017 [citado 13 out. 2018]. Disponível em: https://www.congressoservicosocialuel.com.br/anais/2017/assets/134367.pdf.

12. Almeida C. Parcerias público-privadas (PPP) no setor saúde: processos globais e dinâmicas nacionais. Cad Saude Publica. 2017;33(Suppl 2):e00197316. http://dx.doi.org/10.1590/0102-311x00197316.

13. Franco A. A reforma do estado e o terceiro setor. In: Bresser-Pereira LC, Wilheim J, Sola $L$, organizadores. Sociedade e estado em transformação. São Paulo: UNESP, 1999. p. 273305.

14. Barbosa AP, Malik AM. Desafios na organização de parcerias público-privadas em saúde no Brasil: análise de projetos estruturados entre janeiro de 2010 e março de 2014 . Rev Adm Publica. 2015;49(5):1143-65. http://dx.doi.org/10.1590/0034-7612136177.

15. Silva AC, Batista JHS, Santos WCM. Desmonte do SUS: o ataque neoliberal à política de saúde no brasil. Anais 7. Seminário Frente Nacional contra a Privatização da Saúde. 27-29 out. 2017 [citado 20 out. 2018]. Disponível em: www.seer.ufal.br/index.php/anaisseminariofncps/article/download/4009/2847.

16. Santana GD, Rodrigues Júnior HS. As parcerias Público-Privadas: Solução ou problema? Primas. 2006;3(1):148-81. https://doi.org/10.5102/prismas.v3i1.210.

17. Porto LFG. Gastos tributários e o financiamento do Sistema Único de Saúde -SUS: os efeitos sobre a equidade e o modelo de atenção à saúde. J Manag Prim Health Care. 2019;11(Suppl 1):e52s. https://doi.org/10.14295/jmphc.v11iSup.871. 
18. Viacava F, Oliveira RAD, Carvalho CC, Laguardia J, Bellido JG. SUS: oferta, acesso e utilização de serviços de saúde nos últimos 30 anos. Cienc Saude Colet. 2018:23(6):175162. https://doi.org/10.1590/1413-81232018236.06022018.

19. Tribunal de Contas da União (BR). Relatório de Levantamento da Advocacia-Geral da União: levantamento sobre governança pública em âmbito nacional e análise sistêmica das oportunidades de melhoria constatadas e atuação conjunta dos tribunais de contas do Brasil. [Brasília, DF: TCU; 2014].

20. Morais HMM, Albuquerque MSV, Oliveira RS, Cazuzu AKI, Silva NAF. Organizações sociais da saúde: uma expressão fenomênica da privatização da saúde o Brasil. Cad Saude Publica 2018;34(1):e00194916. https://doi.org/10.1590/0102-311X00194916.

21. Mendes KDS, Silveira RCCP, Galvão CM. Revisão integrativa: método de pesquisa para a incorporação de evidências na saúde e na enfermagem. Texto Contexto Enferm. 2008;17(4):758-64. https://doi.org/10.1590/S0104-07072008000400018.

22. Ribeiro GMA. O Sistema Único de Saúde ante as perspectivas da terceirização administrativa. [tese]. Manaus: Universidade do Estado do Amazonas; 2018.

23. Machado CV. O SUS e a privatização: tensões e possibilidades para a universalidade e o direito à saúde. Cad Saude Publica. 2018;34(7):e00116218, 2018. https://doi.org/10.1590/0102-311X00116218.

24. Melo MP, Lessa SEC. Políticas de saúde, neoliberalismo e o crescimento do chamado terceiro setor: uma análise das FASFIL do campo da saúde no Censo IBGE 2005. Textos Contextos (Porto Alegre). 2017;16(1):262-74. https://doi.org/10.15448/16779509.2017.1.24602.

25. Barreto FL, Souza CC; Luedy A, Mendes VLPS, Tahara ÂTS. Processo de gestão hospitalar em parceria público-privada. Rev Baiana Saude Publica. 2016;40(supl. 1):133-53. https://doi.org/10.22278/2318-2660.2016.v40.n0.a2672.

26. Lara L, Guareschi NMF, Bernardes AG. Reforma sanitária e a privatização da saúde em um contexto biopolítico de garantia de direitos. Psicol Soc. 2016;28(2):360-8. https://doi.org/10.1590/1807-03102016v28n2p360.

27. Feitosa RL, Montenegro AV. Considerações sobre terceirização e precarização do trabalho no contexto brasileiro: uma revisão. Rev Psicol. 2015;6(2):76-89. 
28. Albuquerque M SV, Morais HMM, Lima LP. Contratualização em saúde: arena de disputa entre interesses públicos e privados. Cien Saude Colet. 2015;20(6):1825-34. https://doi.org/10.1590/1413-81232015206.11862014.

29. Campos CMS, Viana N, Soares CB. Mudanças no capitalismo contemporâneo e seu impacto sobre as políticas estatais: o SUS em debate. Saude Soc. 2015;24(supl.1):82-91. https://doi.org/10.1590/s0104-12902015s01007.

30. Scheffer M. O capital estrangeiro e a privatização do sistema de saúde brasileiro. Cad Saude Publica. 2015;31(4):663-6. https://doi.org/10.1590/0102-311XPE010415.

31. Contreiras H, Matta GC. Privatização da gestão do sistema municipal de saúde por meio de Organizações Sociais na cidade de São Paulo, Brasil: caracterização e análise da regulação. Cad Saude Publica. 2015;31(2):285-97. https://doi.org/10.1590/0102$311 \times 00015914$.

32. Araújo IMM. Direito à saúde: aspectos do modelo neodesenvolvimentista brasileiro e da privatização da saúde. Rev Direito Sanit. 2015;16(1):128-45. https://doi.org/10.11606/issn.2316-9044.v16i1p128-145.

33. Castro ALB. Atenção primária e relações público-privadas no sistema de saúde do Brasil [tese]. Rio de Janeiro: Escola Nacional de Saúde Pública Sergio Arouca; 2015.

34. Mendes Á. A saúde pública brasileira no contexto da crise do estado ou do capitalismo? Saúde Soc. 2015;24(suppl.1):66-81. https://doi.org/10.1590/s0104-12902015s01006.

35. Rodrigues CT, Spagnuolo RS. Organizações Sociais de Saúde: potencialidades e limites na gestão pública. Rev Eletron Enferm. 2014;16(3):549-57. https://doi.org/10.5216/ree.v16i3.22319.

36. Silva VC. Terceiro setor e parcerias na saúde: as organizações sociais como possibilidades e limites na gerência da Estratégia Saúde da Família [tese]. Rio de Janeiro: Escola Nacional de Saúde Pública Sergio Arouca; 2014.

37. Tavares, V. Privatização, avante!. Poli. 2014;6(35):17-19.

38. Leite AMGN. Organizações sociais de saúde e controle externo: uma análise a partir do Tribunal de Contas de Pernambuco [dissertação]. [Recife]: Centro de Pesquisa Aggeu Magalhães; 2014.

39. Romano CMC, Scatena JHG. A relação público-privada no SUS: um olhar sobre a assistência ambulatorial de média e alta complexidade na região de saúde da Baixada 
Cuiabana em Mato Grosso. Rev Adm Publica. 2014;48(2):439-58.

https://doi.org/10.1590/0034-76121618.

40. Paulus Júnior, A. Alocação de recursos condicionada ao desempenho de prestadores de serviços de saúde: o caso das contratualizações de hospitais por uma Secretaria Municipal de Saúde no Brasil [tese]. Rio de Janeiro: Fundação Oswaldo Cruz. Escola Nacional de Saúde Pública Sergio Arouca; 2013.

41. Travassos C. Comercialização do cuidado de saúde [Editorial]. Cad Saude Publica; 2013;29(5):841-3. https://doi.org/10.1590/S0102-311X2013000500001.

42. Borges FT. Desafios e perspectivas do Sistema Único de Saúde (SUS) diante do neoliberalismo [tese]. Araçatuba: Universidade Estadual Paulista; 2012.

43. Mendes Á. Gestão pública e relação público-privado na Saúde. Cienc Saude Colet. 2011;16(4):2347-50. http://dx.doi.org/10.1590/S1413-81232011000400035.

44. Carneiro Junior N, Nascimento VB, Costa IMC. Relação entre público e privado na Atenção Primária à Saúde: considerações preliminares. Saude Soc. 2011;20(4):971-9. http://dx.doi.org/10.1590/S0104-12902011000400014.

45. Ocké-Reis CO, Sophia DC. Uma crítica à privatização do sistema de saúde brasileiro: pela constituição de um modelo de proteção social público de atenção à saúde. Saude Debate. 2009;33(81):72-9.

46. Duarte IG, Botazzo C. Gestão de pessoas nas organizações sociais de saúde: algumas observações. Rev Adm Saude. 2009;11(45):161-8.

47. Amadigi FR, Albuquerque GL, Gonçalves ER, Erdmann AL. A relação público-privado na saúde brasileira: refletindo eticamente sobre os impasses e tendências para o SUS. Cienc Cuid Saude. 2007;6(4):508-13. https://doi.org/10.4025/cienccuidsaude.v6i4.3896.

48. Barata LRB, Mendes JDV. Organizações sociais de saúde: a experiência exitosa de gestão pública de saúde do Estado de São Paulo. São Paulo; [s.n]; jul. 2007. [16] p. tab.

49. Carneiro Junior N, Elias PEM. Controle público e equidade no acesso a hospitais sob gestão pública não estatal. Rev Saude Publica. 2006;40(5):914-20. https://doi.org/10.1590/S0034-89102006000600023. 
ISSN 2179-6750

\section{Minicurrículo}

Fábio Cegatti | ORCiD: 0000-0002-8349-1268

Especialista em Economia e Gestão em Saúde da Faculdade de Saúde Pública da Universidade de São Paulo, Brasil.

Leonardo Carnut | ORCiD: 0000-0001-6415-6977

Professor Adjunto do Centro de Desenvolvimento do Ensino Superior em Saúde, Universidade Federal de São Paulo, SP, Brasil.

Áquilas Mendes | ORCiD: 0000-0002-5632-4333

Professor Dr. Livre-Docente de Economia Política da Saúde da Faculdade de Saúde Pública da Universidade de São Paulo (USP) e do Programa de Pós-Graduação em Economia Política e do Departamento de Economia da PUC-SP. 